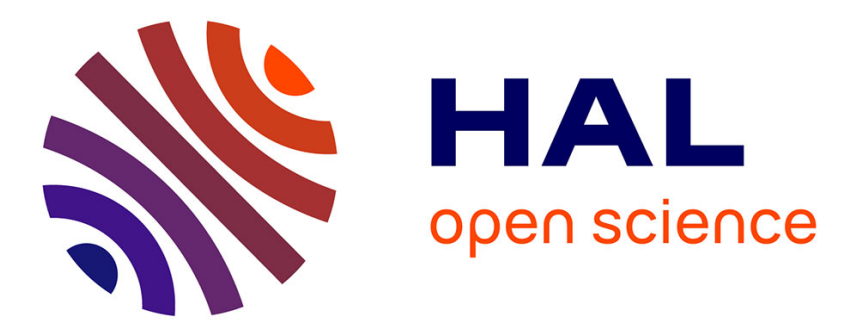

\title{
Influence of EGR and Syngas Components on the Autoignition of Natural Gas in a Rapid Compression Machine: A Detailed Experimental Study
}

\author{
Y. Yu, G. Vanhove, J. Griffiths, S. de Ferrières, J.-F. Pauwels
}

\section{To cite this version:}

Y. Yu, G. Vanhove, J. Griffiths, S. de Ferrières, J.-F. Pauwels. Influence of EGR and Syngas Components on the Autoignition of Natural Gas in a Rapid Compression Machine: A Detailed Experimental Study. Energy \& Fuels, 2013, 27 (7), pp.3988 - 3996. 10.1021/ef400336x . hal-01738389

\author{
HAL Id: hal-01738389 \\ https://hal.science/hal-01738389
}

Submitted on 14 Sep 2020

HAL is a multi-disciplinary open access archive for the deposit and dissemination of scientific research documents, whether they are published or not. The documents may come from teaching and research institutions in France or abroad, or from public or private research centers.
L'archive ouverte pluridisciplinaire HAL, est destinée au dépôt et à la diffusion de documents scientifiques de niveau recherche, publiés ou non, émanant des établissements d'enseignement et de recherche français ou étrangers, des laboratoires publics ou privés. 


\section{Influence of EGR components on the autoignition of natural gas in a rapid compression machine: a detailed experimental study}

\begin{tabular}{|r|l|}
\hline Journal: & Energy \& Fuels \\
\hline Manuscript ID: & Draft \\
\hline Manuscript Type: & Article \\
\hline Date Submitted by the Author: & n/a \\
\hline Complete List of Authors: & $\begin{array}{l}\text { Yu, Yi; PC2A - UMR 5822 CNRS/Lille 1, } \\
\text { Vanhove, Guillaume; PC2A - UMR 5822 CNRS/Lille 1, } \\
\text { Griffiths, John; School of Chemistry, } \\
\text { De Ferrières, Solène; CRIGEN - Centre de Recherche et Innovation en Gaz } \\
\text { et Energies Nouvelles, } \\
\text { Pauwels, Jean-François; PC2A - UMR 5822 CNRS/Lille 1, }\end{array}$ \\
\hline
\end{tabular}

SCHOLARONE ${ }^{\text {m }}$

Manuscripts 


\title{
Influence of EGR components on the autoignition of natural gas in a rapid compression machine: a detailed experimental study
}

\author{
Y. Yu ${ }^{1}$, G. Vanhove ${ }^{1,{ }^{*}}$, J.F. Griffiths ${ }^{2}$, S. De Ferrières ${ }^{3}$, J.-F. Pauwels $^{1}$ \\ ${ }^{1}$ PC2A - UMR 5822 CNRS/Lille 1. Université Lille1 Sciences et Technologies, Cité \\ scientifique, 59655 Villeneuve d'Ascq Cedex, France \\ ${ }^{2}$ School of Chemistry, The University, Leeds, LS2 9JT, United Kingdom. \\ ${ }^{3}$ CRIGEN - Centre de Recherche et Innovation en Gaz et Energies Nouvelles, GDF \\ SUEZ, 361 Avenue du Président Wilson, 93210 St Denis la Plaine, France
}

*: Corresponding author Guillaume Vanhove PC2A - UMR 8522 CNRS/Lille 1

Université de Lille 1 - Sciences et Technologies Cité scientifique 59655 Villeneuve d'ascq CEDEX France

Tel: +333.20 .43 .44 .85$

Fax: +333.20.43.69.77

e-mail: guillaume.vanhove@univ-lille1.fr 


\begin{abstract}
A detailed experimental study was performed in a rapid compression machine to investigate the effect of several EGR components on the autoignition of natural gas. Ignition delays of methane, natural gas and mixtures of natural gas with hydrogen, carbon monoxide, carbon dioxide and water were measured for temperatures ranging from $870 \mathrm{~K}$ to $1000 \mathrm{~K}$ and pressures from 18 to 24 bar, at equivalence ratios 1 and 0.7. The results show an accelerating effect of $\mathrm{H}_{2}$ blending. The experimental measurements are compared with results from numerical simulations using detailed chemical mechanisms from the literature. Natural gas ignition delays can be reproduced satisfactorily, but improvements need to be made to give an accurate, quantitative account of the effect of the inclusion hydrogen.
\end{abstract}

Keywords: RCM, natural gas, ignition, EGR, hydrogen. 


\section{Introduction}

Natural gas (NG) is widely recognised as a very convenient automotive fuel: its high $\mathrm{H} / \mathrm{C}$ ratio involves lower $\mathrm{CO}_{2}$ emissions than conventional fuels; it has high combustion efficiency, it induces lower $\mathrm{CO}$ and unburned hydrocarbons emissions and has a low propensity to knock [1]. It is readily available as a fossil resource, but can also be synthesised from biomass [2-4]. As a consequence, surrogate compositions of NG, have been widely studied in combustion systems, including burners [5], rapid compression machines [6-9] and shock tubes [10, 11]. Investigations prior to 1994 were reviewed by Spadaccini and Colkett [12]. It is well understood that the reactivity of natural gas is correlated to its content of higher hydrocarbons, such as ethane and propane, especially in the low and intermediate temperature regime $[7,8,13-16]$.

However, the use of EGR technology in modern engines, as well as the eventual presence of impurities in synthesised NG, indicates a need for detailed studies on the effect of additional components on the ignition delays of NG in engine conditions. The present study relates to the inclusion of $\mathrm{H}_{2}, \mathrm{CO}, \mathrm{CO}_{2}$ and $\mathrm{H}_{2} \mathrm{O}$ individually in mixtures with natural gas and the experimental investigation of the subsequent variation of ignition delay following compression in a rapid compression machine ( $\mathrm{RCM})$ to temperatures in the range $880-960 \mathrm{~K}$ and pressures in the range $18-22$ bar.

The addition of hydrogen to gaseous fuels has the advantage of reducing $\mathrm{CO}_{2}$ emissions when hydrogen is obtained from non-fossil resources. However, this addition can have an effect on the knock propensity of the fuel in spark ignition engines, which also needs to be addressed [17]. Carbon monoxide also has some 
part to play as a reactive, heat generating component but carbon dioxide and water have largely inert roles, apart from the potential for limited, kinetic contributions or through their enhanced heat capacity relative to that of monatomic or diatomic molecules.

The purpose of the present investigation is to provide experimental data to elucidate how these supplementary components affect the autoignition of a typical NG composition. Experimental comparisons are also made between the combustion of NG and pure $\mathrm{CH}_{4}$. In addition, with the distinctions between $\mathrm{NG}$ and pure $\mathrm{CH}_{4}$ in mind, in order to guide further developments that may be necessary for the application of numerical investigations to the influence of EGR components on NG combustion, we also explore, briefly, the potential success of several, comprehensive kinetic models that have been developed for methane combustion in reproducing the ignition delays that we have measured using natural gas.

\section{Previous related studies}

Ignition delay measurements and numerical simulations have been made of the effect of hydrogen addition on the combustion of methane in shock tubes [18-21] and a rapid compression machine [22]. The investigation by Zhang et al [21] covers a complete composition range $\left(100 \% \mathrm{CH}_{4}\right.$ to $100 \% \mathrm{H}_{2}$ as fuel) at pressures from $5-20$ bar and temperatures from 1020 - $1750 \mathrm{~K}$, and is accompanied by extensive numerical simulations and kinetic analyses. In each of these studies [18-22], an increase of the global rate of oxidation at any given temperature was observed when hydrogen was added in increasing proportions.

Recently, with interests in the use of syngas, Gersen et al [23] measured ignition delays of stoichiometric and fuel-lean mixtures, comprising $\mathrm{H}_{2}, \mathrm{H}_{2} / \mathrm{CO}, \mathrm{CH}_{4}, \mathrm{CH}_{4} / \mathrm{CO}$, 
$\mathrm{CH}_{4} / \mathrm{H}_{2}$ and $\mathrm{CH}_{4} / \mathrm{CO} / \mathrm{H}_{2}$, in an RCM at pressures ranging from 20 to 80 bar over the compressed gas temperature range 900-1100 K. Ignition delays were shortest for $\mathrm{H}_{2}$ under comparable conditions to other mixtures, and those of $\mathrm{CH}_{4}$ were the longest. The replacement of $30 \% \mathrm{CH}_{4}$ by $\mathrm{H}_{2}$ had a significant effect on $\mathrm{CH}_{4}$ ignition, the delays falling between those of the single component fuels. The effects of $\mathrm{CO}$, at $50 \%$ of the fuel with $\mathrm{H}_{2}$ and at $20 \%$ of the fuel with both $\mathrm{CH}_{4}$ and $\mathrm{CH}_{4} / \mathrm{H}_{2}$ mixtures, were found to be negligible. The addition of syngas to $\mathrm{CH}_{4}$ resulted in ignition behavior that resembled an equivalent $\mathrm{CH}_{4} / \mathrm{H}_{2}$ mixture containing the same $\mathrm{H}_{2}$ fraction. The experimental observations were reproduced satisfactorily in numerical simulations.

Although a helpful approach because it simplifies the interpretation of the kinetic effects, the study of methane as a surrogate for NG has limitations because, in reality, the heavier hydrocarbons that are present in NG also have a marked influence on methane oxidation. Thus, a complementary investigation of the ignition response of NG to the inclusion of EGR and syngas components is appropriate.

However, little kinetic work has been done so far using natural gas/hydrogen mixtures. Dagaut and Dayma [24] studied the kinetics of oxidation of $\mathrm{CH}_{4} / \mathrm{C}_{2} \mathrm{H}_{6} / \mathrm{H}_{2}$ mixtures in a high pressure (10 atm) Jet-Stirred Reactor (JSR), between 900 and $1200 \mathrm{~K}$. They showed that the oxidation of the $\mathrm{CH}_{4} / \mathrm{C}_{2} \mathrm{H}_{6}$ mixture is enhanced by the addition of $\mathrm{H}_{2}$, and attribute the reactivity enhancement to an increase in the concentrations of $\mathrm{H}, \cdot \mathrm{OH}$ and $\mathrm{HO}_{2} \cdot$ radicals when hydrogen is present in the initial mixtures. De Ferrières et al. [25] added 20 to $60 \% \mathrm{H}_{2}$ to $\mathrm{NG}$ in a low pressure flat flame and measured the concentration profiles of the reactants and products in order to study the kinetic effects of hydrogen addition. Their conclusion was that, under 
their conditions, the channels involving $\mathrm{H}$-abstraction by $\mathrm{H}^{\cdot}$ atoms are increasingly favoured, as is the formation of $\mathrm{CO}$ over $\mathrm{CO}_{2}$.

Prior to the work reported in [23] the ignition of pure $\mathrm{H}_{2} / \mathrm{O}_{2}$ and $\mathrm{H}_{2} / \mathrm{CO} / \mathrm{O}_{2}$ mixtures was investigated in an RCM by Mittal et al. [26] under a wide range of experimental conditions, and the kinetic importance of $\mathrm{HO}_{2}$ radicals and of $\mathrm{H}_{2} \mathrm{O}_{2}$ was emphasised through numerical simulation.

The large heat capacity of carbon dioxide, compared to that of nitrogen or argon, has led to its frequent use as an inert gas for RCM studies under $700 \mathrm{~K}$ [27]. But the effect of $\mathrm{CO}_{2}$ blending on $\mathrm{CH}_{4}$ ignition at higher temperatures is limited to the study of the addition of large quantities of $\mathrm{CO}_{2}$ to $\mathrm{CH}_{4}$ /air mixtures in a JSR at $10 \mathrm{~atm}$, between 900 and $1450 \mathrm{~K}$, by Le Cong and Dagaut [28]. They showed that $\mathrm{CO}_{2}$ has a thermal effect which reduces flame temperatures, as well as a chemical effect that is likely to proceed through the reduction of the concentration of $\mathrm{H}^{\cdot}$ atoms via $\mathrm{CO}_{2}+\mathrm{H}^{\text {. }}$ $=\mathrm{CO}+\mathrm{OH}$.

To our knowledge, there are no reported studies on the effect of added water on the ignition delay of NG, although Christensen and Johansson [29] have shown that the addition of water could be used to delay the ignition time in an $\mathrm{HCCl}$ engine fuelled with natural gas.

\section{Experimental}

The experiments were carried out in the RCM at the University of Lille. This RCM has a right-angle design, which ensures that the volume is kept strictly constant at the end of the compression. The full details of this facility have been described elsewhere $[9,27,30-32]$. The pressure profiles during operation of the RCM are measured by a 
Kistler 601A piezoelectric pressure transducer with a $40 \mu$ s time step. The ignition delay time is defined as the time between the end of the compression (TDC: Top Dead Centre) and the maximum rise of the pressure associated with ignition. The core gas temperature $\left(T_{C}\right)$ is calculated following the adiabatic core model from the pressure at TDC and the initial conditions $[30,33,34]$. The compression ratio was 11:1 and the cylinder and combustion temperature walls were maintained at $90^{\circ} \mathrm{C}$.

The gas mixtures were prepared in a glass mixing facility, using the partial pressures method, and left to homogenise overnight. The dilution of all mixtures by inert gases $\left(N_{2}, A r\right)$ was identical to that of the proportion of $N_{2}$ in air. The natural gas used in this study was composed of $89 \%$ methane, $9 \%$ ethane and $2 \%$ propane. The gases were provided by Air Liquide with the following purities: NG $\left(9.00 \pm 0.18 \% \mathrm{C}_{2} \mathrm{H}_{6}, 2.00 \pm\right.$ $0.18 \% \mathrm{C}_{3} \mathrm{H}_{8}$ in $\left.\mathrm{CH}_{4}\right), \mathrm{CH}_{4}(99.95 \%), \mathrm{H}_{2}(99.999 \%), \mathrm{O}_{2}, \mathrm{~N}_{2}$ and $\operatorname{Ar}(99.99 \%), \mathrm{CO}$ (99.91\%), $\mathrm{CO}_{2}(99.95 \%)$. Carbon monoxide was stored in an aluminium cylinder to avoid $\mathrm{Fe}(\mathrm{CO})_{5}$ formation [35]. The composition of the $\mathrm{N}_{2} / \mathrm{Ar}$ inert gas mixture was varied, so changing the ratio of heat capacities in order to reach the different core gas temperatures investigated.

Mixtures containing $\mathrm{H}_{2} \mathrm{O}$ were prepared in a heated mixture preparation facility [36] to avoid its condensation. Its temperature was fixed at $80{ }^{\circ} \mathrm{C}$, and the tubing between the facility and the RCM was also heated to $80{ }^{\circ} \mathrm{C}$. At this temperature, the vapour pressure of water is more than $47 \mathrm{kPa}$, whereas the maximum water partial pressure used during mixture preparation was less than $5 \mathrm{kPa}$. The water was purified from dissolved gases by several freezing/pumping cycles.

It has been shown earlier [35] that when measuring ignition delays in the presence of $\mathrm{H}_{2}$, non-uniform ignition can be a major concern, and the presence of particles has been discussed as a possible cause for these non-uniform ignitions. To avoid this 
eventuality a Millipore filter $(0.5 \mu \mathrm{m})$ was installed between the gas mixture preparation facility and the RCM. No difference was observed between results performed with and without the filter for the mixture with the highest hydrogen content. As a consequence, most of the experiments were performed without utilizing the filter.

Non-reactive pressure profiles were acquired for each reactive mixture by replacing $\mathrm{O}_{2}$ by $\mathrm{N}_{2}$. These profiles reveal the rate and extent of the pressure fall due to cooling in the boundary layer after the end of compression and they enable an accurate reproduction of the heat loss, based on adiabatic expansion of the core gas, to be obtained in zero-dimensional simulations [37]. The corresponding mixture compositions and "thermal diffusivity" values, as well as the non-reactive pressure profiles, are available from the authors for all mixtures studied.

The right-angle design of this RCM allows the compression time to be varied without changing the compression ratio. The influence of the compression time on natural gas ignition was therefore investigated, as shown in Section 3. Following the recommendations of Lee and Hochgreb [38], a creviced piston head was used, to ensure maximum homogeneity of the temperature field in the core gas at the end of the compression.

\section{Experimental Results}

A comparison of a reactive and a non-reactive pressure profile is presented for an $\mathrm{NG} / \mathrm{H}_{2}$ mixture, in Figure 1. Heat release during the development of autoignition is sufficiently small for there to be no discernible difference in the pressure profiles until a relatively late stage. Figure 2 sums up the results obtained for the effect of the 
variation of the compression time on ignition delay measurement. At high piston velocities, it shows variations of the TDC pressure increase, and also that the decrease of the pressure after TDC occurs in two distinct phases. This is partly due to vibration which induces a periodic perturbation of the pressure signal, but also from possible non-ideal effects such as turbulence dissipation, and consequent mixing of the adiabatic core with the boundary layer. Adequate reproduction of the heat loss with the core gas expansion model [37] is then made very difficult. At the other extreme, too long a compression time would increase the opportunity for reaction to occur during the compression phase. A compression time of $60 \mathrm{~ms}$ was therefore chosen, as in previous work [9,27,30-32].

A comparison of ignition data obtained with a flat piston and a creviced piston was performed at a compression time of $60 \mathrm{~ms}$, as shown on Figure 3. The ignition delays using the flat piston appear to be slightly longer than those with the creviced piston, suggesting that there is a limited effect of a roll up vortex. These experimental results were simulated using the NUIG mechanism [16].The simulation results are also plotted in Figure 3, and show little difference between the flat piston and the creviced piston results. The modelling of the results using core gas expansion into the boundary layer gives acceptable results in both cases [37].

Measurements of ignition delay for a range of reactive mixtures, using the creviced piston crown, are shown in Figures 4-11 and presented in the following sub-sections, The lines are included as $\beta$-spline fits to the experimental data, and the indicated pressures are the minimum and maximum values reached at TDC. The compressed gas pressure variation results from the increased gas temperature for a fixed initial pressure of each composition, in the range 80.0 - $106.7 \mathrm{kPa}$, as the heat capacity of the mixture is decreased. 


\section{Methane}

Autoignition delay times for stoichiometric $(\Phi=1.0)$ methane/"air" mixtures and at $\Phi$ $=0.7$ have been measured. Their variation with $T_{C}$ was investigated over the temperature range $880-1000 \mathrm{~K}$ at compressed gas pressures in the range 20.5 22.7 bar, as presented in Figure 4. The studies of stoichiometric $\mathrm{CH}_{4}$ /"air" mixtures were restricted to an upper compressed gas temperature of $950 \mathrm{~K}$ at the given compression ratio, as a result of their higher overall heat capacity relative to those for the compositions at $\Phi=0.7$ (Figure 4), for which $1000 \mathrm{~K}$ could be reached. Ignition delays are longer for $\Phi=0.7$ mixtures, especially at the lower temperatures. This is consistent with the results of Healy et al. [7].

In this and other cases, at the lowest compressed gas temperature for ignition the ignition delay becomes very sensitive to variation between experiments, as its duration tends asymptotically to infinity. This scatter of the data may also be influenced by a gradual reduction of the core volume owing to heat loss competing with the low exothermicity of reaction, in the early stages of the ignition delay.

\section{Natural Gas}

Figure 5 shows the decrease of the ignition delays of stoichiometric NG/"air" mixtures with increasing $T_{C}$ at three different initial pressures. Ignition was still possible at $T_{C}<$ $900 \mathrm{~K}$, at the higher initial pressures, but it was not observed below $915 \mathrm{~K}$ at an initial pressure of $80 \mathrm{kPa}$. The enhanced reactivity of NG in a stoichiometric mixture relative to that at $\phi=0.7$ is presented in Figure 6. 
A comparison between the measured ignition delays for stoichiometric $\mathrm{CH}_{4}$ /"air" and NG/"air" mixtures, in Figure 7, demonstrates the marked sensitisation of methane autoignition to the presence of ethane (9\%) and propane (2\%).

\section{Natural gas blending with hydrogen}

The effect of hydrogen blending to natural gas has been studied for fuel fractions $\mathrm{X}_{\mathrm{H} 2} /\left(\mathrm{X}_{\mathrm{H} 2}+\mathrm{X}_{\mathrm{NG}}\right)=0.2$ and 0.6. The measured ignition delays are plotted as a function of $T_{C}$ in Figure 8: That the presence of hydrogen reduces the ignition delay of natural gas is clear, but there are interesting, additional features. That is, there is a significant reduction of the ignition delay when NG is replaced by $20 \% \mathrm{H}_{2}$ but the sensitivity to a further increase of $\mathrm{H}_{2}$ to $60 \%$ is very slight. Moreover, from the data obtained either side of $\mathrm{T}_{\mathrm{C}} \sim 905 \mathrm{~K}$ at the two compositions, the reproducibility of the experiments is sufficiently good to show a cross-over of the ignition delay dependence on the proportion of $\mathrm{H}_{2}$. The $80 / 20 \mathrm{NG} / \mathrm{H}_{2}$ mixture appears to be the less reactive mixture below $905 \mathrm{~K}$, as expected, but the slightly more reactive of the two above this temperature.

\section{Natural gas blending with carbon monoxide}

In order to evaluate the effect of carbon monoxide on the ignition delays of natural gas, a partial substitution of NG by CO was made, at fuel proportions ranging from 10 to $30 \%$ in the reactant mixture, while keeping the equivalence ratio constant at $\phi=$ 1.0. The ignition delays are plotted as a function of $T_{c}$ on Figure 9.Carbon monoxide appears to have no discernible effect on the ignition delays of natural gas. 


\section{Natural gas blending with carbon dioxide}

Several $\mathrm{NG} / \mathrm{CO}_{2}$ mixtures were studied by addition of $\mathrm{CO}_{2}$ up to $\mathrm{x}_{\mathrm{CO} 2} /\left(\mathrm{x}_{\mathrm{NG}}+\mathrm{x}_{\mathrm{CO} 2}\right)=$ 0.3, the equivalence ratio of the NG being kept constant. At its highest proportion, the $\mathrm{CO}_{2}$ constitutes about $4 \%$ by volume of the total reactant mixture. This has a small effect of increasing the overall heat capacity and so decreases the temperature reached at the end of compression to a limited extent. As can be seen on Figure 10, no effect on the ignition delay could be discerned. The proportion is very low compared with the $20 \%$ mole fraction of $\mathrm{CO}_{2}$ in the mixtures studied by Le Cong and. Dagaut [28]. Adding a compound with a relatively high heat capacity to the mixture is likely to have an effect on the variation of temperature induced by the heat release. This can result in a variation of the ignition delays, as described by Würmel et al. [39], but no such effect was observed in our conditions with relatively low $\mathrm{CO}_{2}$ mole fractions.

\section{Natural gas blending with Water}

Water was introduced in our mixtures, in a way similar to that of $\mathrm{CO}_{2}$, at a proportion of $30 \%$ relative to the fuel. As shown on Figure 11 , there appears to be no effect of water addition on the ignition delay at compressed gas temperatures above $910 \mathrm{~K}$. However, as in the case of $\mathrm{CO}_{2}$, there is a reduction of the core gas temperatures reached at the end of the compression as a result of the addition of water to the mixtures.

\section{Summary of the effects of EGR components}

The results obtained with all of the EGR components are summarised in Figure 12, for $T_{C}$ between 917 and $936 \mathrm{~K}$. The core gas temperatures were not strictly identical 
for different additive fuel fractions because the heat capacities of each fuel/additive mixture varied to a limited extent. This small variation in $T_{C}$ was sufficient to affect the measured ignition delays through the overall activation energy of the reaction rate, and this accounts for the scatter in the case of $\mathrm{H}_{2} \mathrm{O}$ and $\mathrm{CO}_{2}$ blending, which is marked within the grey zone in Figure 12. This marked zone corresponds to an increase or a decrease of the ignition delay by less than $20 \%$. Only hydrogen has a discernible effect in reducing the ignition delay, as the proportion of hydrogen in the fuel was increased from 0 to $60 \%$. The other additives hardly influence the ignition delay, up to proportions equivalent to $30 \%$ of the fuel.

\section{Discussion}

By virtue of the presence of higher alkanes $\left(9 \mathrm{~mol} \% \mathrm{C}_{2} \mathrm{H}_{6}\right.$ and $\left.2 \mathrm{~mol} \% \mathrm{C}_{3} \mathrm{H}_{8}\right)$ the significant enhancement of the autoignition of $\mathrm{NG}$ relative to that of $\mathrm{CH}_{4}$ is evident throughout the temperature range investigated in the present experiments. There is further enhancement of the reactivity when $\mathrm{H}_{2}$ is substituted for $\mathrm{NG}$, albeit with a much reduced sensitivity at high proportions of $\mathrm{H}_{2}$. The lack of sensitivity to the replacement of NG by CO shows that CO plays some part in the kinetics and heat release in the overall reaction. If $\mathrm{CO}$ were to act predominantly as an inert diluent, then we would expect there to be an increase in the ignition delay consistent with the response of NG at $\phi=0.7$ relative to that of $N G$ at $\phi=1.0$. This is corroborated by Mittal et al [40], who showed that the ignition delay in $\mathrm{H}_{2} / \mathrm{N}_{2}$ mixtures was longer than that in corresponding $\mathrm{H}_{2} / \mathrm{CO}$ compositions, at above $1000 \mathrm{~K}$, especially when the proportion of $\mathrm{CO}$ or $\mathrm{N}_{2}$ exceeded $50 \%$ of the 'fuel' component. The behaviour of NG in the presence of $\mathrm{CO}$ observed in the present work is similar to ignition data 
obtained by Gersen et al [23], both for $\mathrm{CH}_{4} / \mathrm{CO}$ and $\mathrm{H}_{2} / \mathrm{CO}$ mixtures relative to those from $\mathrm{CH}_{4}$ and $\mathrm{H}_{2}$ respectively. By contrast, at the extreme, the sensitization of $\mathrm{CO}$ ignition by very small amounts of $\mathrm{H}_{2}$, or other hydrogenous compounds, has been known for a considerable time and is well documented [41].

\section{Tests of methane kinetic models applied to natural gas autoignition}

The purpose of this final part of our discussion is to explore the extent to which various comprehensive kinetic models for methane combustion may be applied successfully to the simulation of the present experimental measurements of ignition delay involving a natural gas of known composition.

The simulations were performed using the Chemkin package [42], assuming timedependent volume profile to simulate the expansion of the core gas into the boundary layer [37]. The natural gas composition used in the simulations comprised methane/ethane/propane $=89 / 9 / 2 \%$, as in the experiments. Four models were considered: The LENI model [9], the NUIG model [16], the USC model [43], and the GRI 3.0 model with the RAMEC sub-mechanism $[44,45]$.

In previous work, the LENI model has been tested against RCM data using a synthetic methane/ethane/propane mixture with a similar composition to the present NG [9]. The NUIG model has been validated on a large number of mixtures, including 90/6.6/3.3, 70/15/15, and 70/20/10 methane/ethane/propane mixtures, expressed as percentages, as well as mixtures containing higher hydrocarbons [7]. The USC model has been applied to a large variety of high-temperature ignition delay measurements for hydrogen and single component $C_{1}$ to $C_{3}$ hydrocarbons [21]. The RAMEC submechanism has been developed to extend the validation of the GRI mechanism to intermediate temperatures shock tube methane ignition delays [45]. 
The comparison between the experimental and the simulated ignition delays is presented in Figure 13. It shows that the present natural gas results are best simulated by the NUIG model, with which the agreement, for a stoichiometric mixture, is very good throughout the pressures and temperature ranges investigated. The simulation of experimental investigations of $\mathrm{CH}_{4}$ autoignition, to which similar components were blended, also gives a very satisfactory validation of the NUIG model [23]. There is a reasonable representation of the present NG data using the LENI model, albeit with a consistent under-prediction of the ignition delay by approximately $50 \%$. It is conspicuous that the models that have not been set up with adequate representation of the kinetic interactions involving ethane and propane do not, generally, predict sufficiently high reactivity and fail to capture the combustion leading to ignition at the lowest core gas temperatures.

In a supplementary analysis, simulations were made to explore the extent to which reaction may occur during the compression phase, based on the velocity profile of the piston, and comparing the results with the non-compression simulation adopted in the earlier calculations. The position - time profile of the experiments is available from the authors on request. As shown in Figure 14, whereas there is no evidence of significant reaction having started during the compression phase of NG alone, the decrease of the predicted ignition delay in the case of $\mathrm{NG}-\mathrm{H}_{2}$ mixtures indicates that some reactivity has occurred during the compression phase.

Finally, the precision with which the effect of EGR components can be predicted using the NUIG model [16] was explored briefly by reference to the data presented in Figure 12. The simulations took into account the possibility of reaction in the compression stroke in the case of hydrogen-containing mixtures. As shown in Figure 15 , the predicted ignition delays of increasing proportions of $\mathrm{CO}_{2}, \mathrm{CO}$ and $\mathrm{H}_{2} \mathrm{O}$ in 
$\mathrm{NG} / \mathrm{CO}_{2}, \mathrm{NG} / \mathrm{CO}$ and $\mathrm{NG} / \mathrm{H}_{2} \mathrm{O}$ mixtures show very little effect on the reactivity of $\mathrm{NG}$. The enhanced reactivity in the presence of increasing proportions of $\mathrm{H}_{2}$ is clearly demonstrated, although the duration of the ignition delay is over-estimated by the model. This may suggest that further model development may be required on the interactions between the kinetic mechanisms between the two fuel components.

\section{Conclusions}

A detailed experimental study of the autoignition of methane, natural gas and natural gas with various additional components, typical of those associated with exhaust gas recirculation, was performed in an RCM. Ignition delays of pure methane/"air" mixtures were measured and found to increase from equivalence ratios 1.0 to 0.7 . These results were compared with those from natural gas, which ignites with a shorter ignition delay at all conditions investigated. Blending hydrogen in the mixture at all volume percentages in the fuel from 20 to $60 \%$ shortens the ignition delay. CO was found to have no effect up to a fuel proportion of $30 \%$. Simulations were performed with the NUIG mechanism: the agreement is overall very good for natural gas and the different additives. In order to be able to reproduce the effect of EGR in real engines conditions, further work might be required to improve the simulation of $\mathrm{H}_{2}$-containing mixtures.

\section{Acknowledgements}

The authors would like to thank GDF SUEZ CRIGEN and the Institut de Recherche en ENvironnement Industriel (IRENI) for financial support of this project. IRENI is 
funded by the Région Nord Pas-de-Calais, the Ministère de l'Enseignement Supérieur et de la Recherche, the CNRS and FEDER. 


\section{References}

[1] T. Korakianitis, A.M. Namasivayam, R.J. Crookes, Prog. Energ. Combust. 37 (2011) 89-112.

[2] M.C. Seemann, T.J. Schildhauer, S.M.A. Biollaz, Ind. Eng. Chem. Res. 49 (2010) 7034-7038.

[3] J. Kopyscinski, T.J. Schildhauer, S.M.A. Biollaz, Fuel 89 (2010) 1763-1783.

[4] R.W.R. Zwart, A. Drift, 15th European Biomass Conference and Exhibition, Berlin, Germany, 2007, p.7-11.

[5] A. El Bakali, P. Dagaut, L. Pillier, P. Desgroux, J.-F. Pauwels, A. Rida, P. Meunier, Combust. Flame 137 (2004) 109-128.

[6] E.L. Petersen, D.M. Kalitan, S. Simmons, G. Bourque, H.J. Curran, J.M. Simmie, Proc. Combust. Inst. 31 (2007) 447-454.

[7] D. Healy, H.J. Curran, J.M. Simmie, D.M. Kalitan, C.M. Zinner, A.B. Barrett, E.L. Petersen, G. Bourque, Combust. Flame 155 (2008) 441-448.

[8] D. Healy, H.J. Curran, S. Dooley, J.M. Simmie, D.M. Kalitan, E.L. Petersen, G. Bourque, Combust. Flame 155 (2008) 451-461

[9] S. Heyne, A. Roubaud, M. Ribaucour, G. Vanhove, R. Minetti, D. Favrat, Fuel 87 (2008) 3046-3054.

[10] C.S. Eubank, M.J. Rabinowitz, W.C. Gardiner Jr, R.E. Zellner, Proc. Combust. Inst. 18 (1981) 1767-1774.

[11] N. Lamoureux, C.E. Paillard, Shock Waves 13 (2003) 57-68.

[12] L.J. Spadaccini and M.B. Colkett, Prog. Energy. Combust. Sci. 20 (1994) 431460

[13] R.M.R. Higgins, A. Williams, Proc. Combust. Inst. 12 (1969) 579-590. 
[14] R.W. Crossley, E.A. Dorko, K. Scheller, A. Burcat, Combust. Flame 19 (1972) 373-378.

[15] M. Frenklach, D.E. Bornside, Combust. Flame 56 (1984) 1-27.

[16] D. Healy, D.M. Kalitan, C.J. Aul, E.L. Petersen, G. Bourque, H. J. Curran, Energy Fuels 24 (2010) 1521-1528.

[17] G.A. Karim, I. Wierzba, Y. Al-Alousi, Int. J. Hydrogen Energy 21 (1996) 625-631.

[18] N. Chaumeix, S. Pichon, F. Lafosse, C-E. Paillard, Int. J. Hydrogen Energy 32 (2007) 2216-2226.

[19] J. Huang, W.K. Bushe, P.G. Hill, S.R. Munshi, Int. J. Chem. Kinet. 38 (2006) 221-233.

[20] E.L. Petersen, J.M. Hall, S.D. Smith, J. de Vries, A.R. Amadio, M.W. Crofton, J. Eng. Gas. Turb. Power 129 (2007) 937-944.

[21] Y. Zhang, Z. Huang, L. Wei, J. Zhang, C. K. Law, Combust. Flame 159 (2012) 918-931.

[22] S. Gersen, N.B. Anikin, A.V. Mokhov, H.B. Levinsky, Int. J. Hydrogen Energy 33 (2008) 1957-1964.

[23] S. Gersen, H. Darmeveil, H. Levinsky, Combust. Flame 159 (2012) 3472 - 3475,.

[24] P. Dagaut, G. Dayma, Int. J. Hydrogen Energy 31 (2006) 505-515.

[25] S. de Ferrières, A. El Bakali, B. Lefort, M. Montero, J.-F. Pauwels, Combust. Flame 154 (2008) 601-623.

[26] G. Mittal, C-J. Sung, R. A. Yetter, Int. J. Chem. Kinet. 38 (2006) 516-529.

[27] R. Minetti, M. Carlier, M. Ribaucour, E. Therssen, L.R. Sochet, Proc. Combust. Inst. 26 (1996) 747-753.

[28] T. Le Cong, P. Dagaut, Combust. Sci. Technol. 180 (2008) 2046-2091.

[29] M. Christensen, B. Johansson, SAE paper SAE1999-01-0182, 1999. 
[30] R. Minetti, M. Ribaucour, M. Carlier, C. Fittschen, L.R. Sochet, Combust. Flame 96 (1994) 201-211.

[31] R. Minetti, M. Carlier, M. Ribaucour, E. Therssen, L.R. Sochet, Combust. Flame 102 (1995) 298-309.

[32] R. Minetti, M. Ribaucour, M. Carlier, L.R. Sochet, Combust. Sci. Technol. 113114 (1996) 179-192.

[33] P. Desgroux, L. Gasnot, L.R. Sochet, Appl. Phys. 61 (1995) 69-72.

[34] C.K. Westbrook, H.J. Curran, W.J. Griffiths, C. Mohamed, S.K. Wo, Proc. Combust. Inst. 27 (1998) 371-378.

[35] M. Chaos, F.L. Dryer, Combust. Sci. Technol. 180 (2008) 1053-1096.

[36] M. Crochet, R. Minetti, M. Ribaucour, G. Vanhove, Combust. Flame 157 (2010) 2078-2085.

[37] S. Tanaka, F. Ayala, J.C. Keck, Combust. Flame 133 (2003) 467-481.

[38] D. Lee, S. Hochgreb, Combust. Flame, 114 (1998) 531-545.

[39] J. Würmel, E.J. Silke, H.J. Curran, M.S. Ó Conaire, J.M. Simmie, Combust. Flame 151 (2007) 289-302.

[40] G.Mittal, C.J. Sung, M. Fairweather, A.S. Tomlin, J.F. Griffiths, K.J. Hughes, Proc. Comb. Inst. 31, 419-427 (2007)

[41] B. Lewis, G. Von Elbe, "Combustion, Flames and Explosions in Gases, $3^{\text {rd }}$ Edition", Academic Press, Orlando, 1987, ISBN 0-12-446751-2

[42] R.J. Kee, F.M. Rupley, J.A. Miller, CHEMKIN-II: A Fortran Chemical Kinetics Package for the Analysis of Gas-Phase Chemical Kinetics, Report NO. SAND 898009B, Sandia National Laboratories, 1991.

[43] H. Wang, X. You, A.V. Joshi, S.G. Davis, A. Laskin, F. Egolfopoulos, C.K. Law, available at <http://ignis.usc.edu/USC_Mech_II.htm>. 
[44] M. Frenklach, H. Wang, C-L. Yu, M. Goldenberg, C.T. Bowman, R.K. Hanson, D.F. Davidson, E.J. Chang, G.P. Smith, D.M. Golden, W.C. Gardiner, V. Lissianski, available at <http://www.me.berkeley.edu/gri_mech/>.

[45] E.L. Petersen, D.F. Davidson, R.K. Hanson, Combust. Flame 117 (1999) 272290. 
Figures

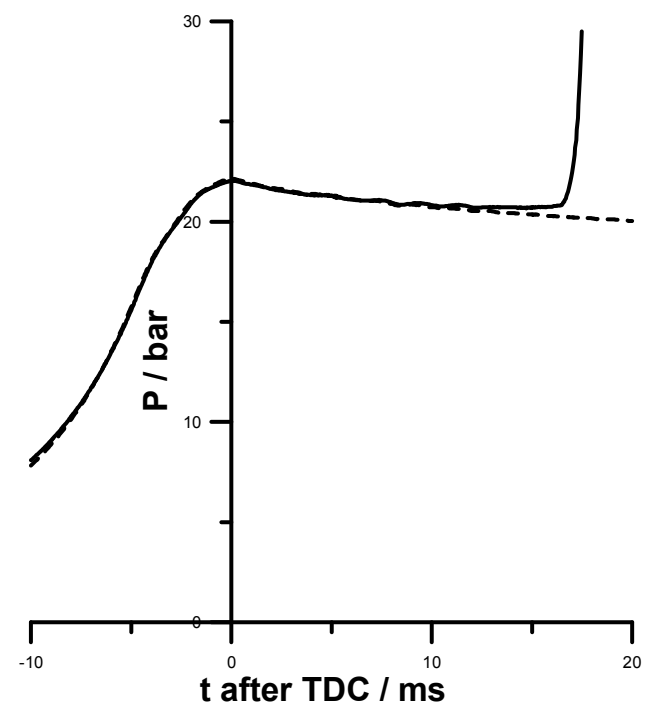

Figure 1

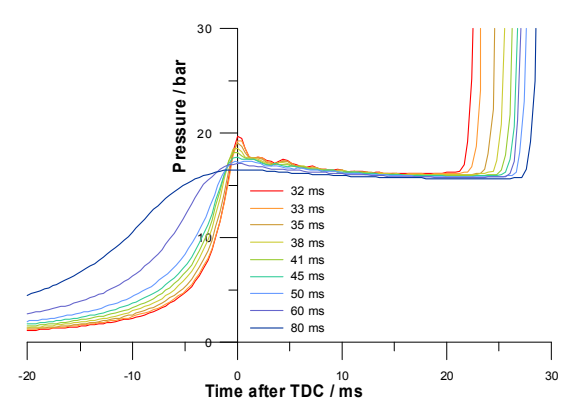

Figure 2. To be printed in colour

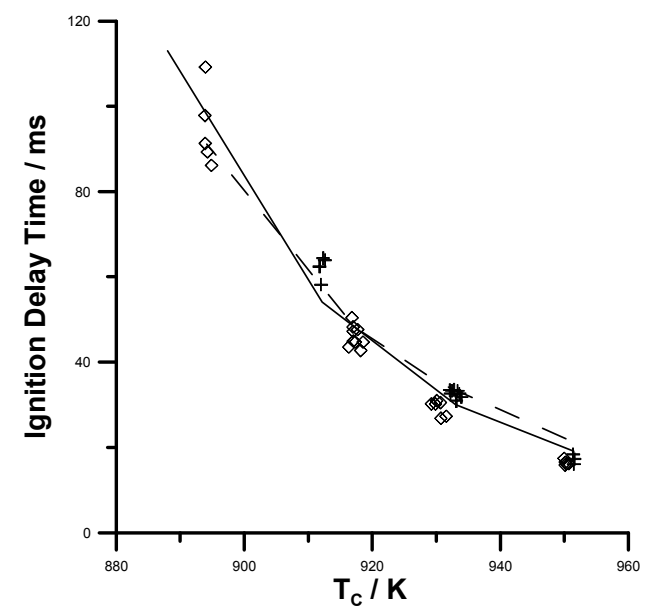

Figure 3 


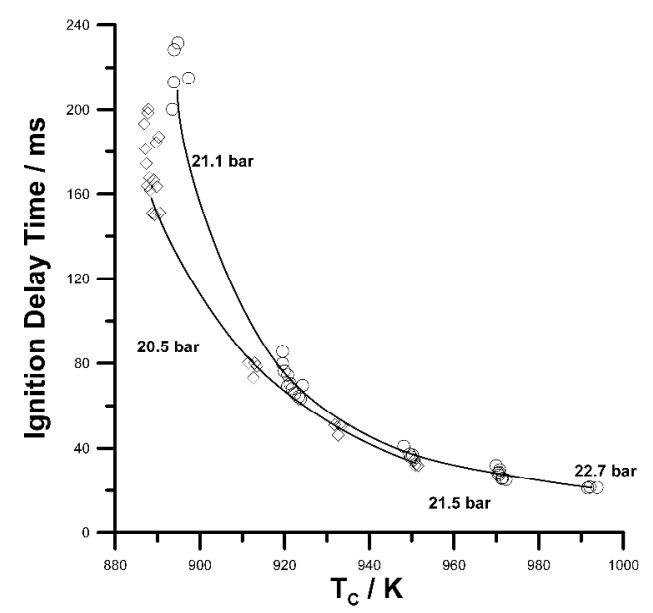

Figure 4

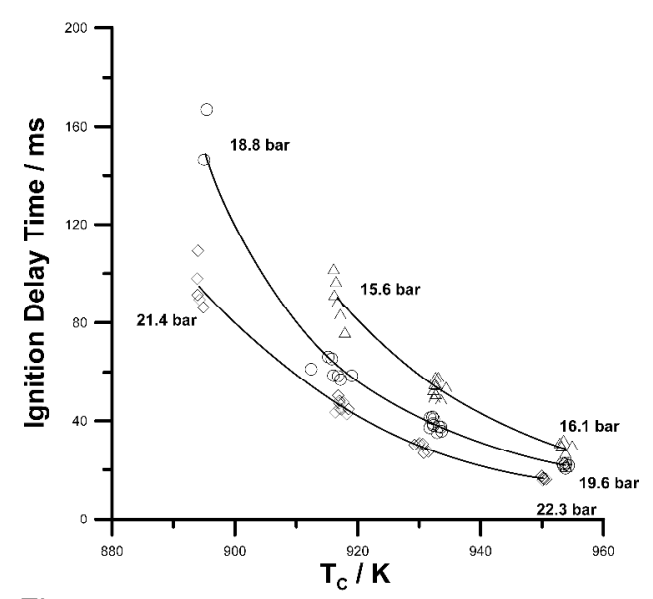

Figure 5

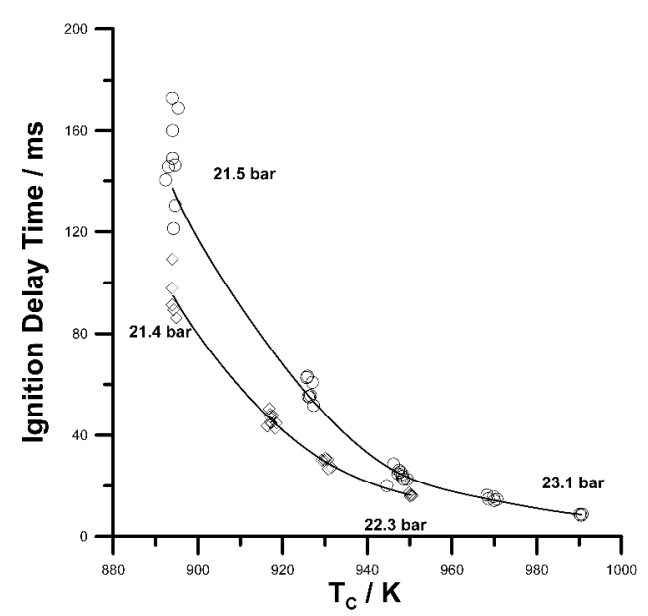

Figure 6 


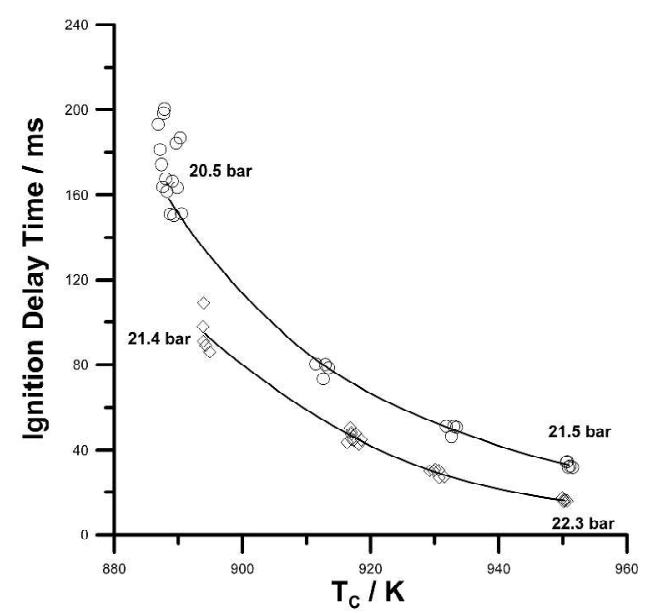

Figure 7

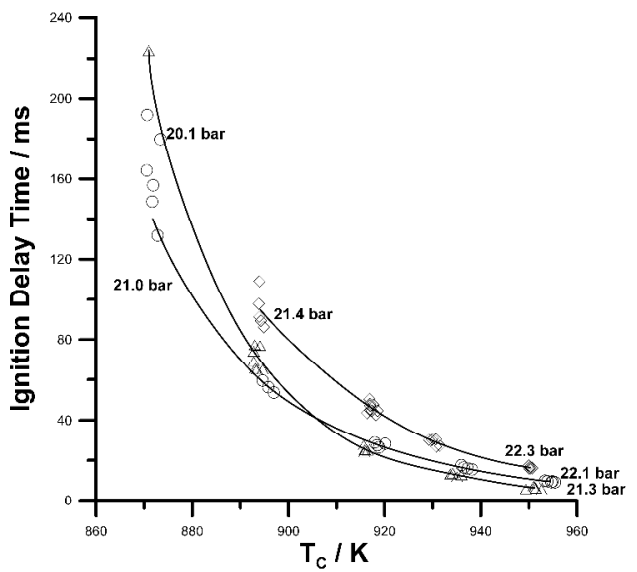

Figure 8

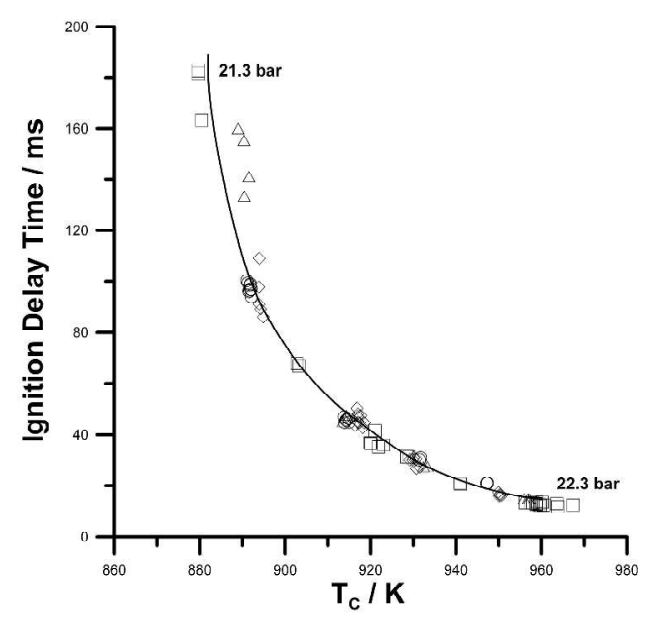

Figure 9 


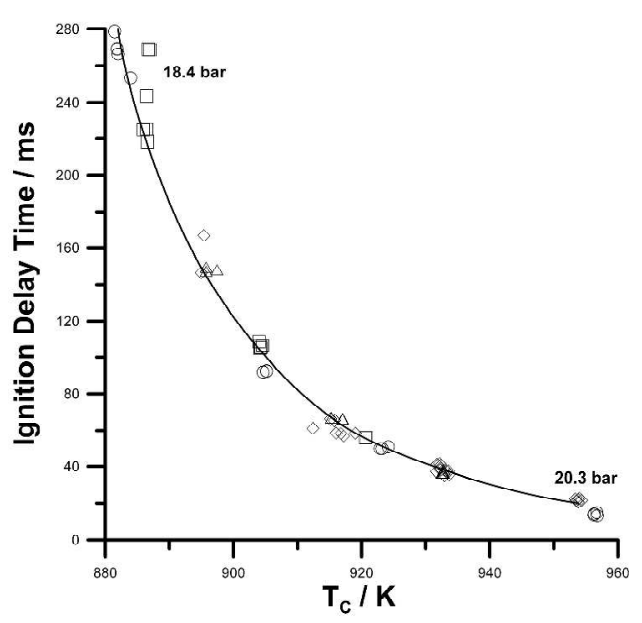

Figure 10

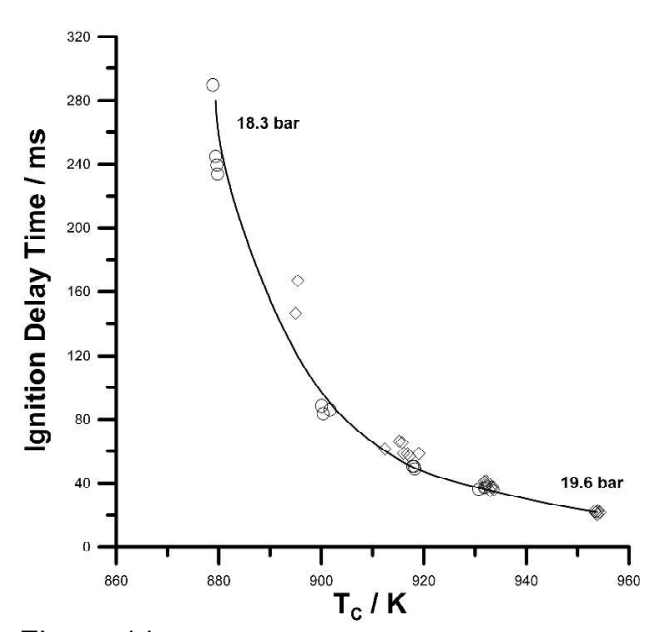

Figure 11

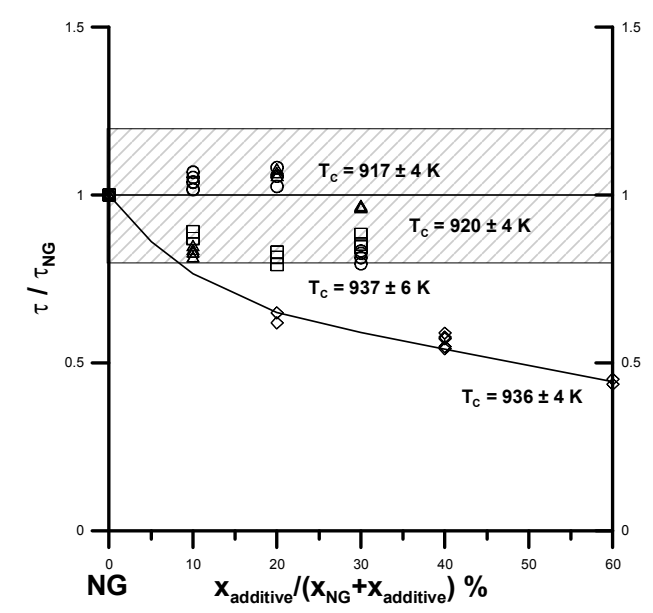

Figure 12

57

58

59

60 


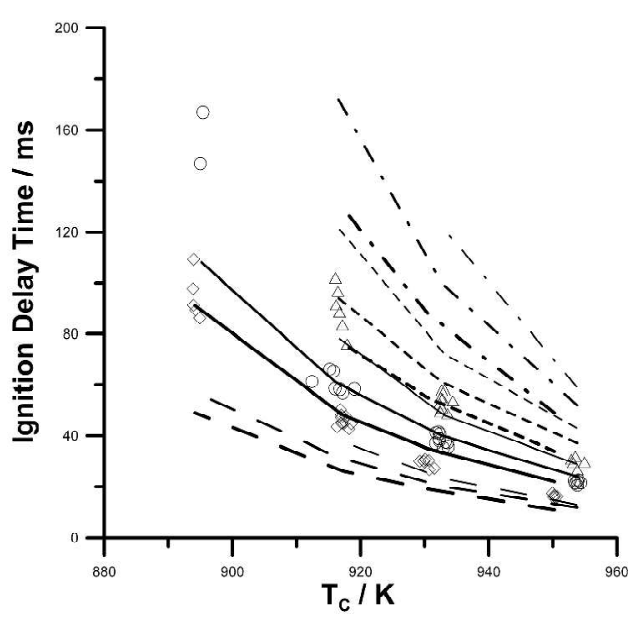

Figure 13

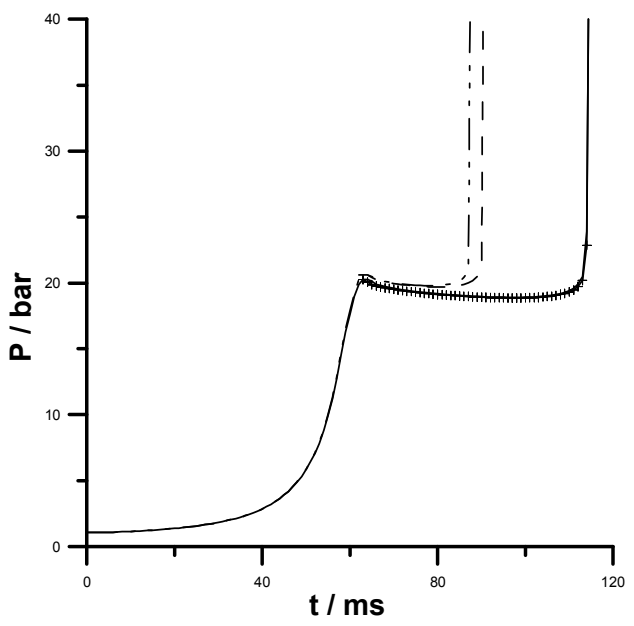

Figure 14

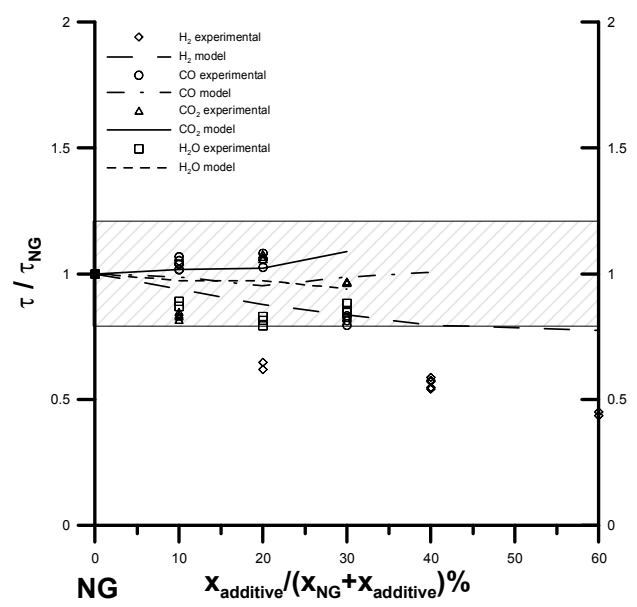

Figure 15 


\section{Figures Captions}

Figure 1: Comparison of the reactive (full line) and the non-reactive (dashed line) pressure profiles in the case of the compression of a $\mathrm{NG} / \mathrm{H}_{2}(80 / 20)$ /"air" mixture. Initial pressure $\mathrm{P}_{0}=106.7 \mathrm{kPa}$, compression time $60 \mathrm{~ms}$.

Figure 2: Effect of the compression time on the pressure profile during a reactive $\mathrm{NG} / \mathrm{O}_{2} / \mathrm{Ar}$ experiment. $\mathrm{P}_{0}=80 \mathrm{kPa}$.

Figure 3: Comparison of the measured (points) and simulated (lines) evolution of the ignition delay times of stoichiometric synthetic natural gas $/ \mathrm{O}_{2} /$ inert mixtures as a function of $\mathrm{T}_{\mathrm{C}}$, for two piston configurations: crosses, full line: flat piston; diamonds, dashed line: creviced piston. Initial pressure $\mathrm{P}_{0}=106.7 \mathrm{kPa}$.

Figure 4: Ignition delay times of stoichiometric (diamonds) and $\Phi=0.7$ (circles) $\mathrm{CH}_{4} / \mathrm{O}_{2} /$ inert mixtures as a function of $\mathrm{T}_{\mathrm{C}}$. Initial pressure $\mathrm{P}_{0}=106.7 \mathrm{kPa}$.

Figure 5: Ignition delay times of stoichiometric $\mathrm{NG} / \mathrm{O}_{2} /$ inert mixtures as a function of TC. Initial pressure : $\mathrm{P}_{0}=80 \mathrm{kPa}$ (triangles), $\mathrm{P}_{0}=93.3 \mathrm{kPa}$ (circles), $\mathrm{P}_{0}=106.7 \mathrm{kPa}$ (diamonds).

Figure 6: Ignition delay times of stoichiometric (diamonds) and $\Phi=0.7$ (circles) $\mathrm{NG} / \mathrm{O}_{2} /$ inert mixtures as a function of $\mathrm{T}_{\mathrm{C}}$. Initial pressure $\mathrm{P}_{0}=106.7 \mathrm{kPa}$.

Figure 7: Ignition delay times of stoichiometric $\mathrm{NG} / \mathrm{O}_{2} /$ inert (diamonds) and $\mathrm{CH}_{4} / \mathrm{O}_{2} /$ inert (circles) mixtures as a function of $\mathrm{T}_{\mathrm{C}}$. Initial pressure: $\mathrm{P}_{0}=106.7 \mathrm{kPa}$.

Figure 8: Ignition delay times of stoichiometric $\mathrm{NG} / \mathrm{O}_{2} /$ inert (diamonds), 80/20 $\mathrm{NG} / \mathrm{H}_{2} / \mathrm{O}_{2} /$ inert (circles) and $40 / 60 \mathrm{NG} / \mathrm{H}_{2} / \mathrm{O}_{2} /$ inert (triangles) mixtures as a function of TC. Initial pressure: $P_{0}=106.7 \mathrm{kPa}$.

Figure 9: Ignition delay times of stoichiometric $\mathrm{NG} / \mathrm{O}_{2}$ /inert (diamonds), 90/10 $\mathrm{NG} / \mathrm{CO} / \mathrm{O}_{2} /$ inert (circles), $80 / 20 \mathrm{NG} / \mathrm{CO} / \mathrm{O}_{2}$ /inert (triangles) and 70/30 NG/CO/O $/$ inert (squares) mixtures as a function of $\mathrm{T}_{\mathrm{C}}$. Initial pressure: $\mathrm{P}_{0}=106.7 \mathrm{kPa}$. 
Figure 10: Ignition delay times of stoichiometric $\mathrm{NG} / \mathrm{O}_{2} /$ inert (diamonds), 90/10 $\mathrm{NG} / \mathrm{CO}_{2} / \mathrm{O}_{2}$ /inert (circles), $80 / 20 \quad \mathrm{NG} / \mathrm{CO}_{2} / \mathrm{O}_{2}$ /inert (triangles) and $70 / 30$ $\mathrm{NG} / \mathrm{CO}_{2} / \mathrm{O}_{2}$ /inert (squares) mixtures as a function of $\mathrm{T}_{\mathrm{C}}$. Initial pressure: $\mathrm{P}_{0}=93.3$ $\mathrm{kPa}$.

Figure 11: Ignition delay times of stoichiometric $\mathrm{NG} / \mathrm{O}_{2} /$ inert (diamonds) and 70/30 $\mathrm{NG} / \mathrm{H}_{2} \mathrm{O} / \mathrm{O}_{2} /$ inert (circles) mixtures as a function of $\mathrm{T}_{\mathrm{C}}$. Initial pressure: $\mathrm{P}_{0}=93.3 \mathrm{kPa}$. Figure 12: Effect of additive blending on the ignition delays of $\mathrm{NG} / \mathrm{O}_{2}$ /inert mixtures. Hydrogen (diamonds): $\mathrm{T}_{\mathrm{C}}=936 \mathrm{~K}, \mathrm{CO}$ (circles): $\mathrm{T}_{\mathrm{C}}=917 \mathrm{~K}, \mathrm{H}_{2} \mathrm{O}$ (squares): $\mathrm{T}_{\mathrm{C}}=937$ $\mathrm{K}, \mathrm{CO}_{2}$ (triangles): $\mathrm{T}_{\mathrm{C}}=920 \mathrm{~K}$.

Figure 13: Comparison of the experimental and simulated ignition delays of stoichiometric $\mathrm{NG} / \mathrm{O}_{2} /$ inert mixtures at three initial pressures: $P_{0}=106.7 \mathrm{kPa}$ (diamonds, thick line), $\mathrm{P}_{0}=93.3 \mathrm{kPa}$ (circles, medium line), $\mathrm{P}_{0}=80 \mathrm{kPa}$ (triangles, thin line). LENI model (long dash), NUIG model (full line), USC model (short dash), GRI+RAMEC (dash-dot).

Figure 14: Simulated pressure profiles obtained in stoichiometric mixtures at $P_{0}=80$ $\mathrm{kPa}$ and $\mathrm{T}_{0}=363 \mathrm{~K}$ for: $\mathrm{NG} / \mathrm{O}_{2} / \mathrm{Ar}$, with the compression phase (full line), without the compression phase (crosses). $\mathrm{NG} / \mathrm{H}_{2}(40 / 60) / \mathrm{O}_{2} / \mathrm{Ar}$, with the compression phase (dash-dotted line), without the compression phase (dashed line).

Figure 15: Comparison of the experimental and simulated effect of additive blending on the ignition delays of $\mathrm{NG} / \mathrm{O}_{2}$ /inert mixtures. Simulations are performed with the NUIG mechanism. Experimental data: see Figure 12. Modelling: $\mathrm{H}_{2}$ (full line), $\mathrm{CO}$ (long dash), $\mathrm{H}_{2} \mathrm{O}$ (dash-dot), $\mathrm{CO}_{2}$ (short dash). 


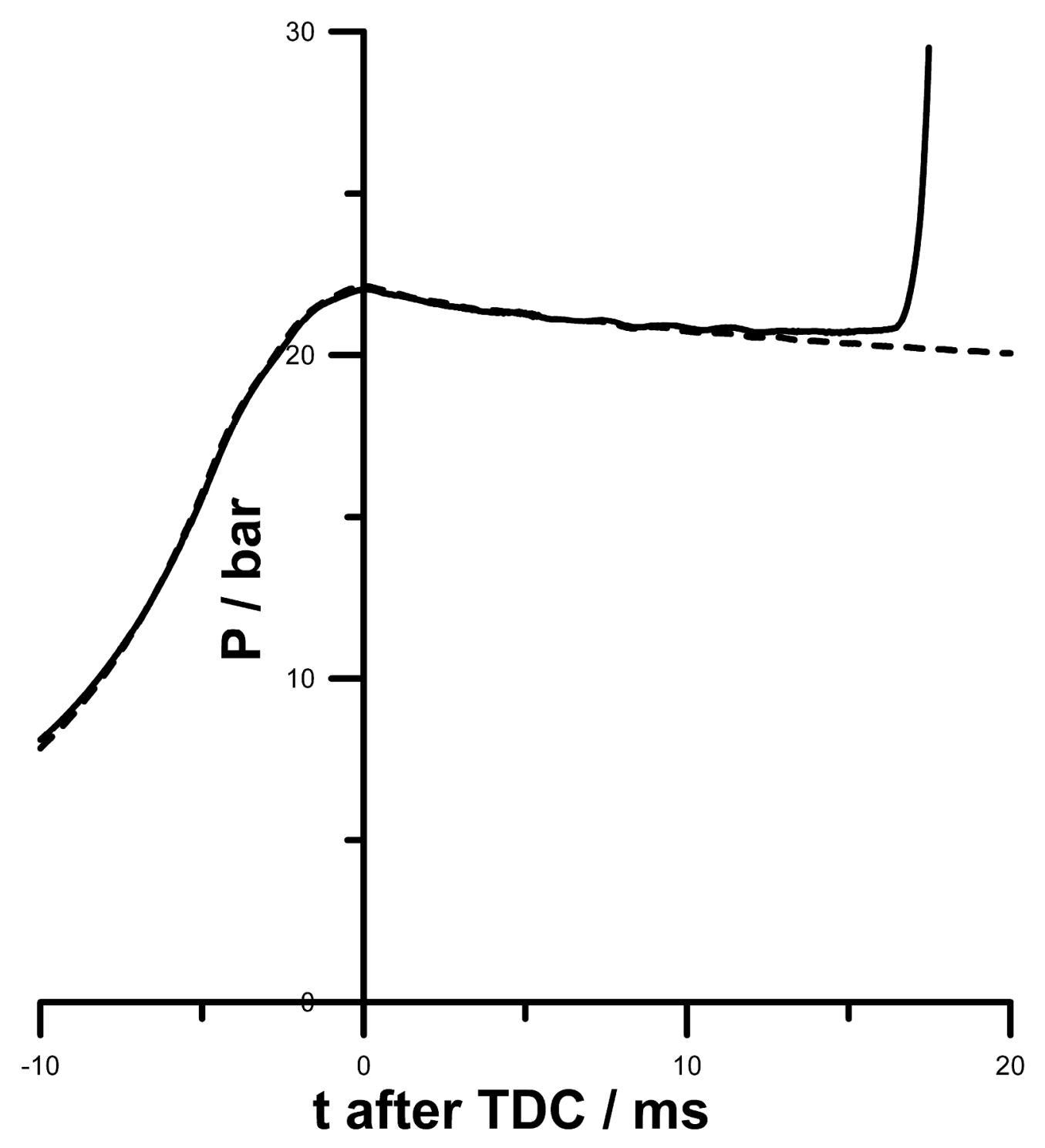

$152 \times 170 \mathrm{~mm}(600 \times 600 \mathrm{DPI})$ 


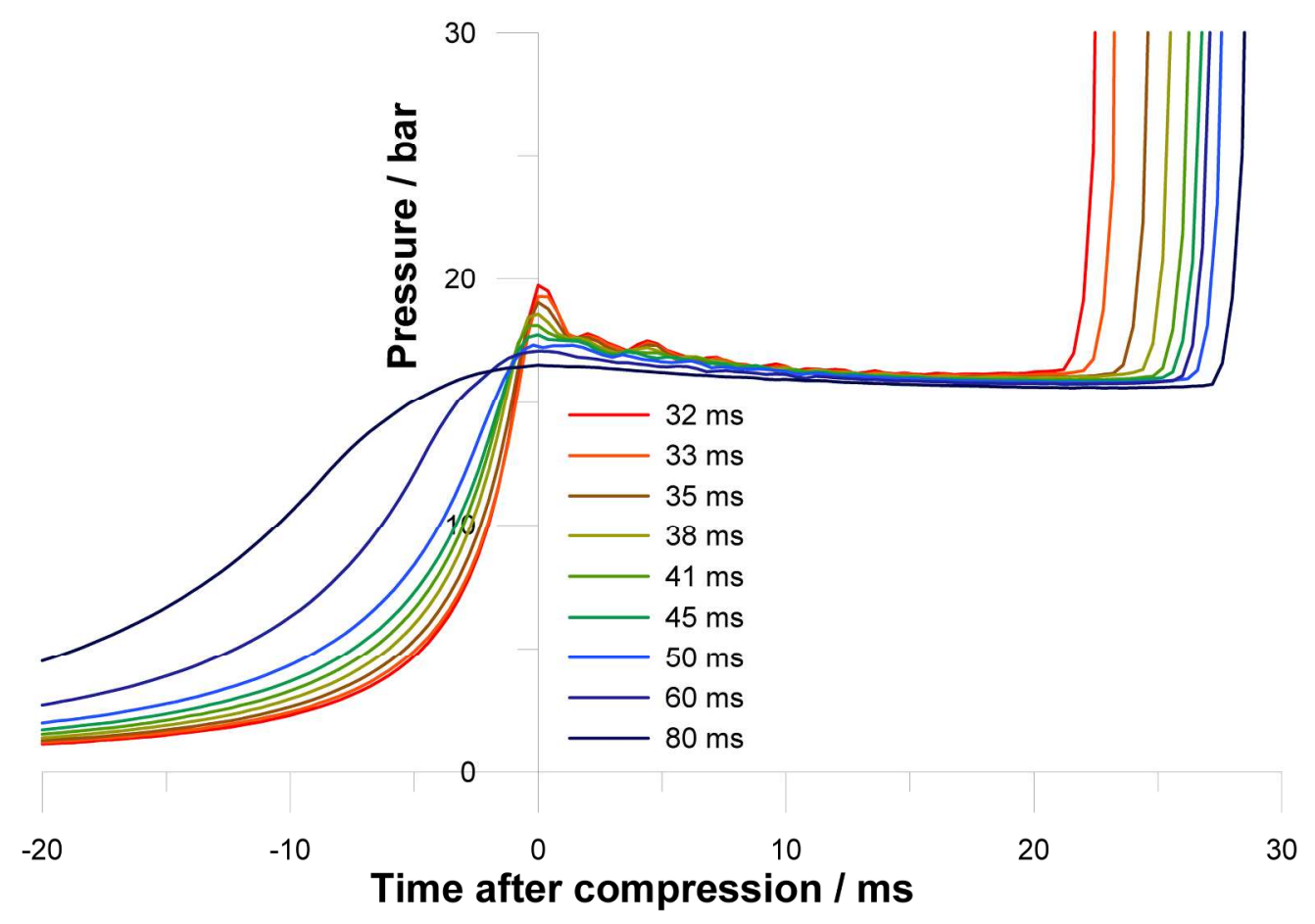

$109 \times 76 \mathrm{~mm}(600 \times 600 \mathrm{DPI})$ 


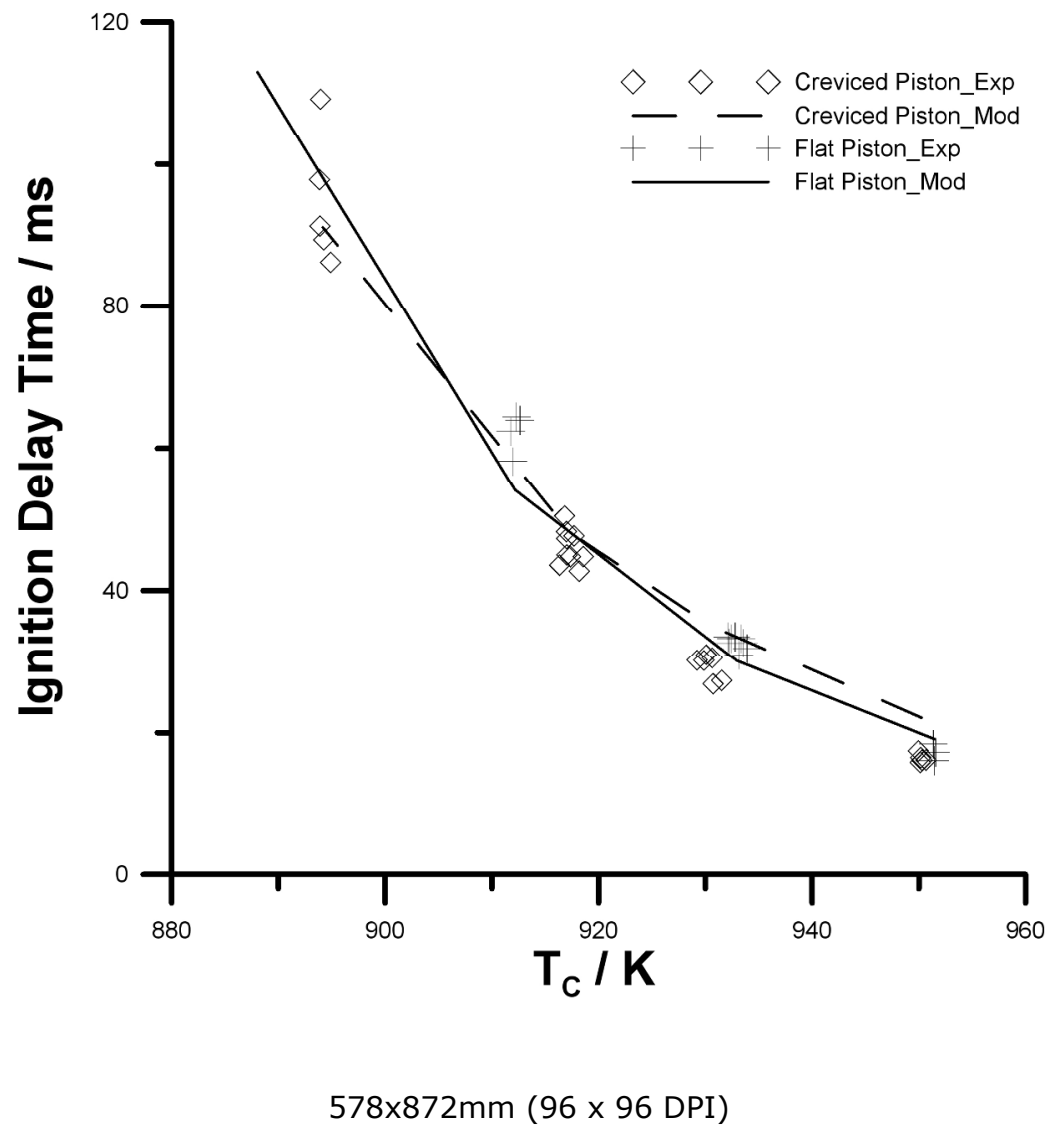




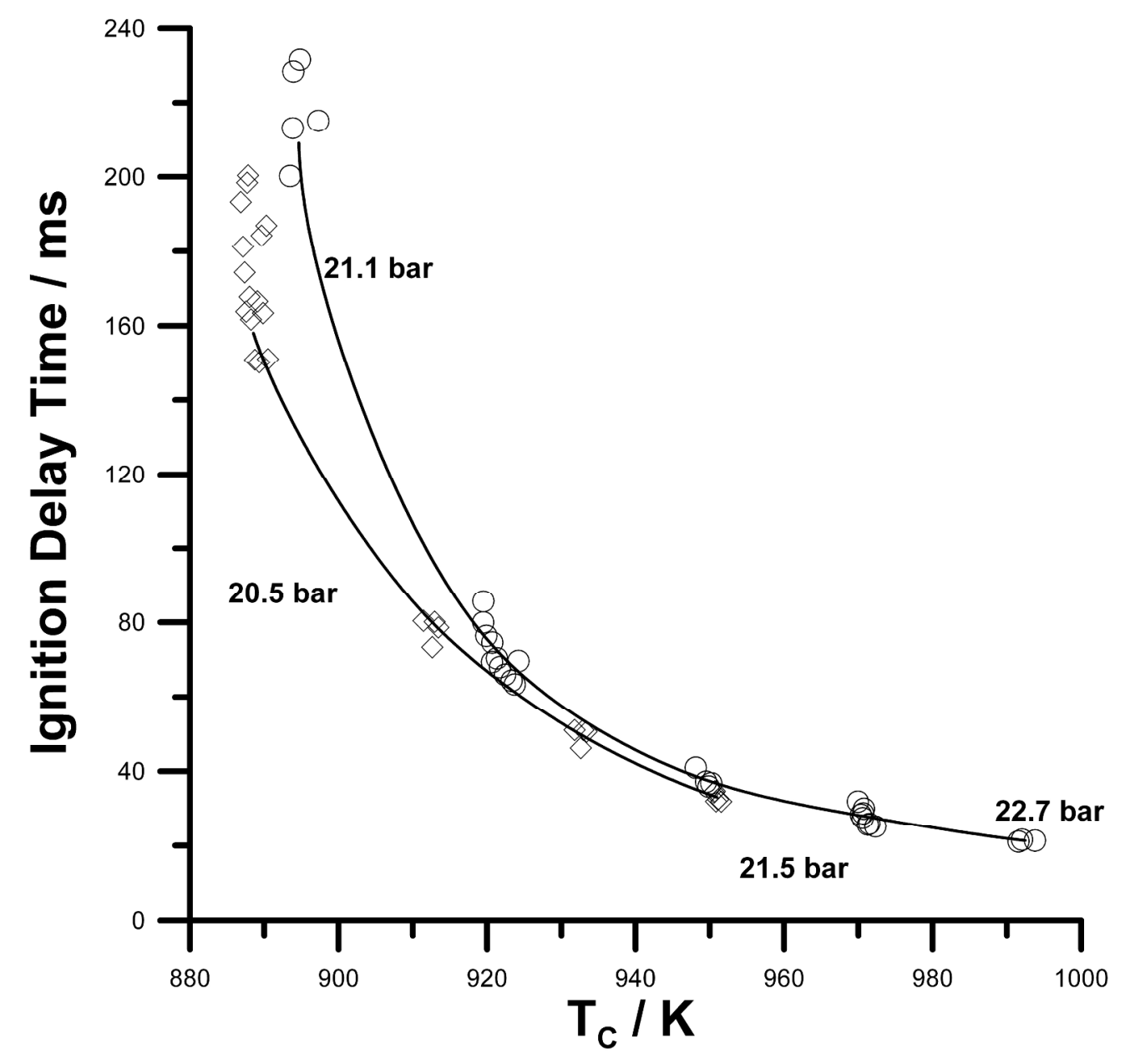

$145 \times 139 \mathrm{~mm}(600 \times 600 \mathrm{DPI})$ 


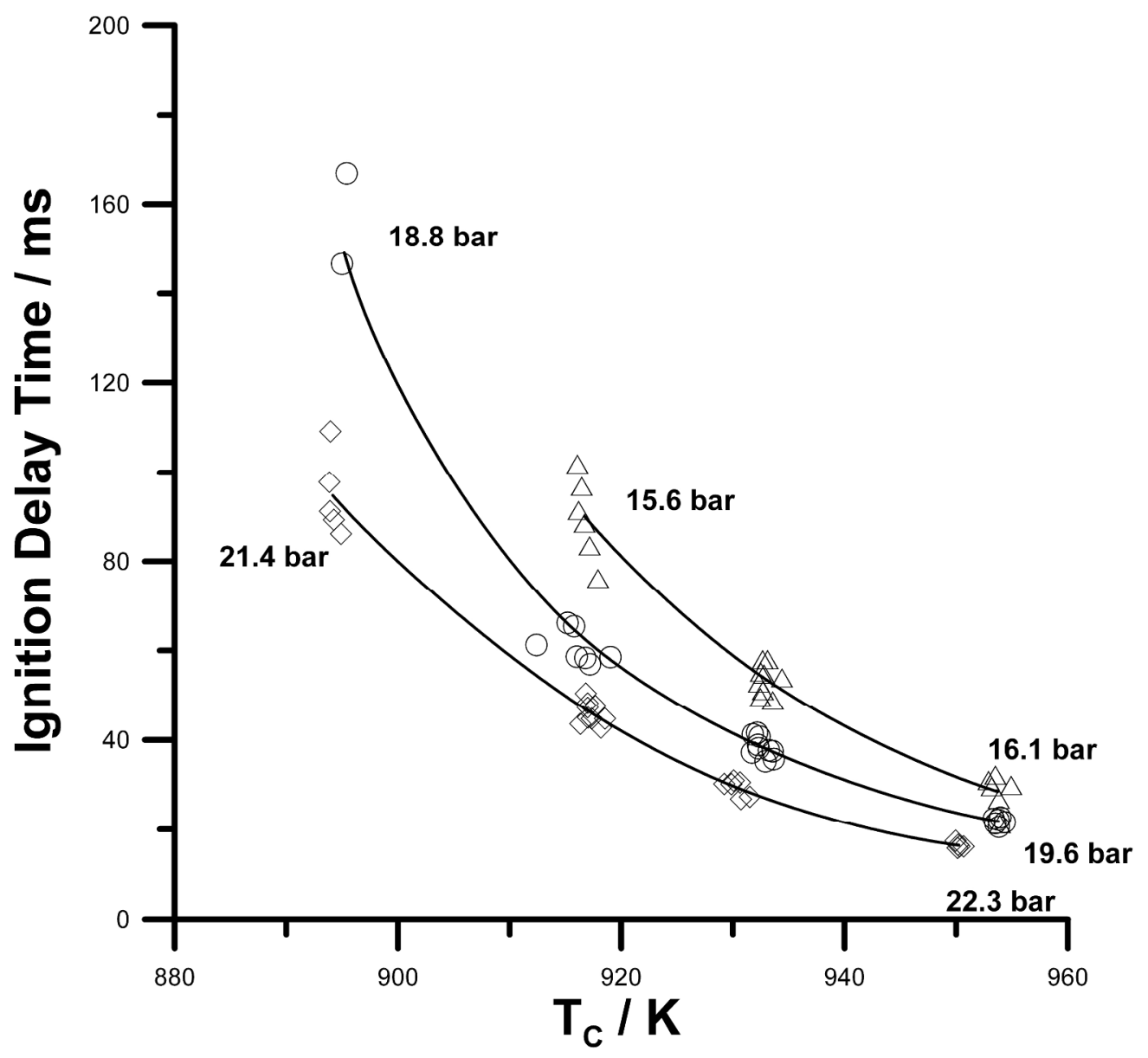

$140 \times 130 \mathrm{~mm}(600 \times 600 \mathrm{DPI})$ 


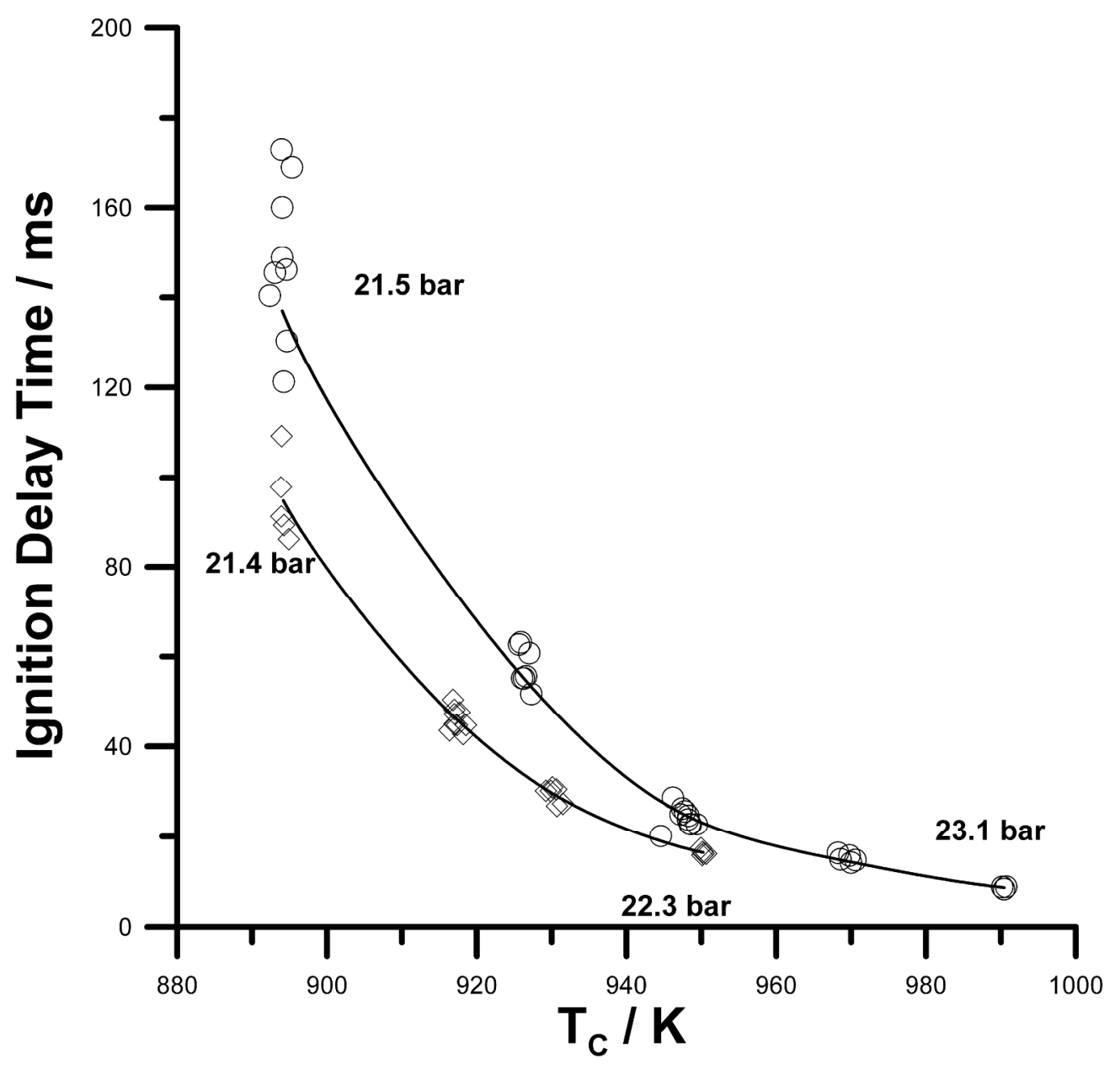

$145 \times 139 \mathrm{~mm}(600 \times 600 \mathrm{DPI})$ 
1

2

3

4

5

6

7

8

9

10

11

12

13

14

15

16

17

18

19

20

21

22

23

24

25

26

27

28

29

30

31

32

33

34

35

36

37

38

39

40

41

42

43

44

45

46

47

48

49

50

51

52

53

54

55

56

57

58

59

60

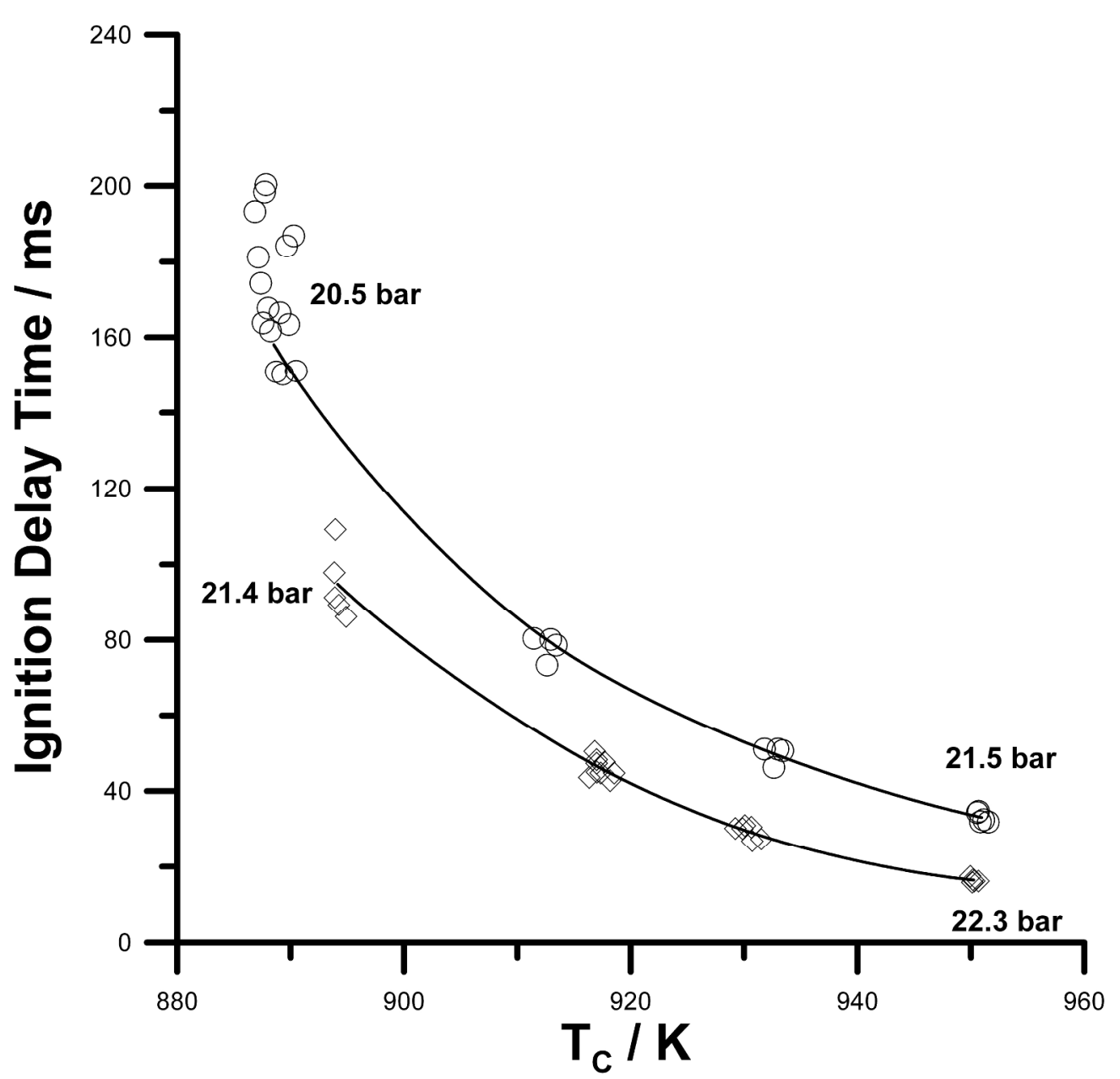

$146 \times 140 \mathrm{~mm}(600 \times 600 \mathrm{DPI})$ 


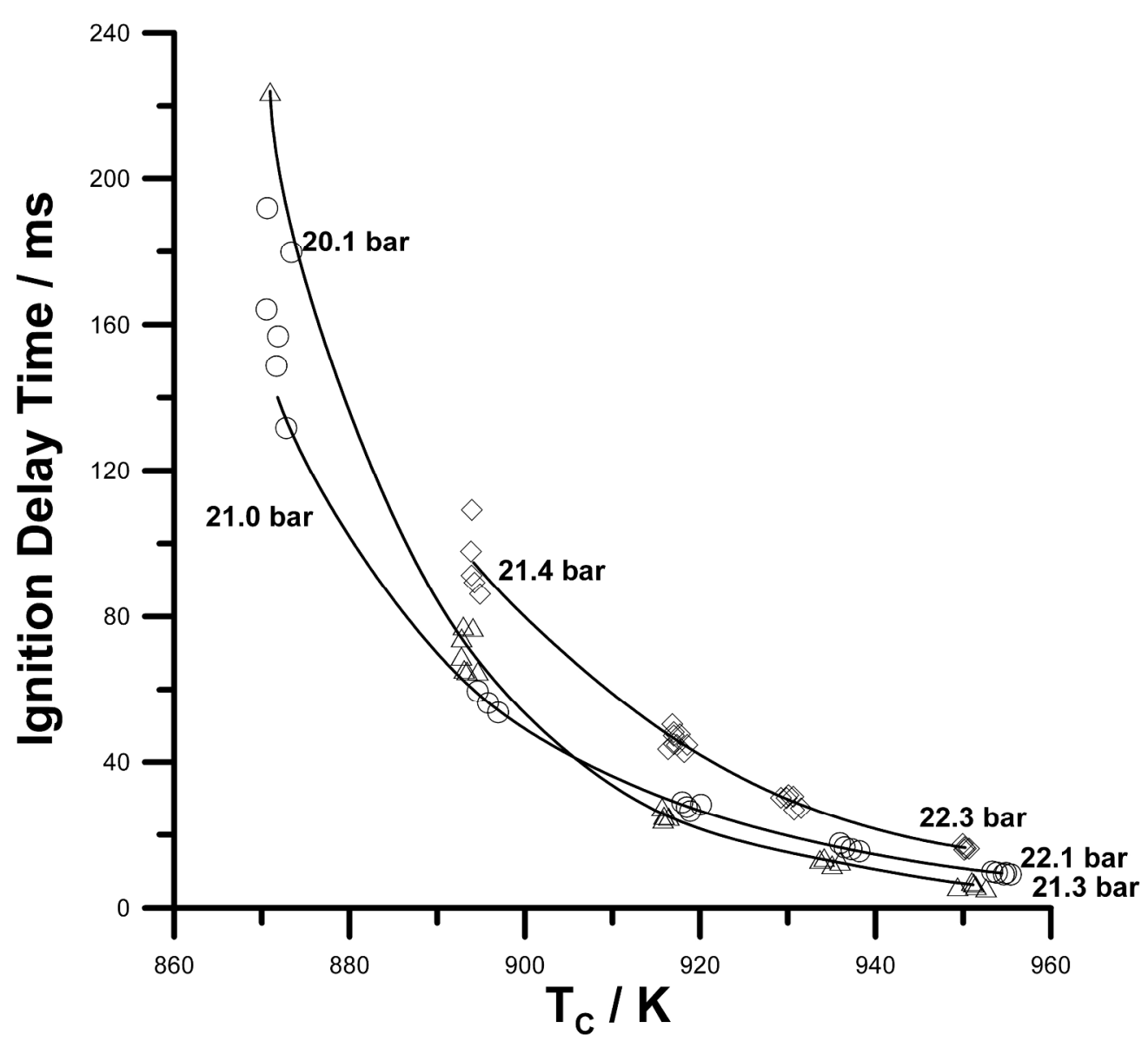

$137 \times 124 \mathrm{~mm}(600 \times 600 \mathrm{DPI})$

39

40

41

42

43

44

45

46

47

48

49

50

51

52

53

54

55

56

57

58

59

60 


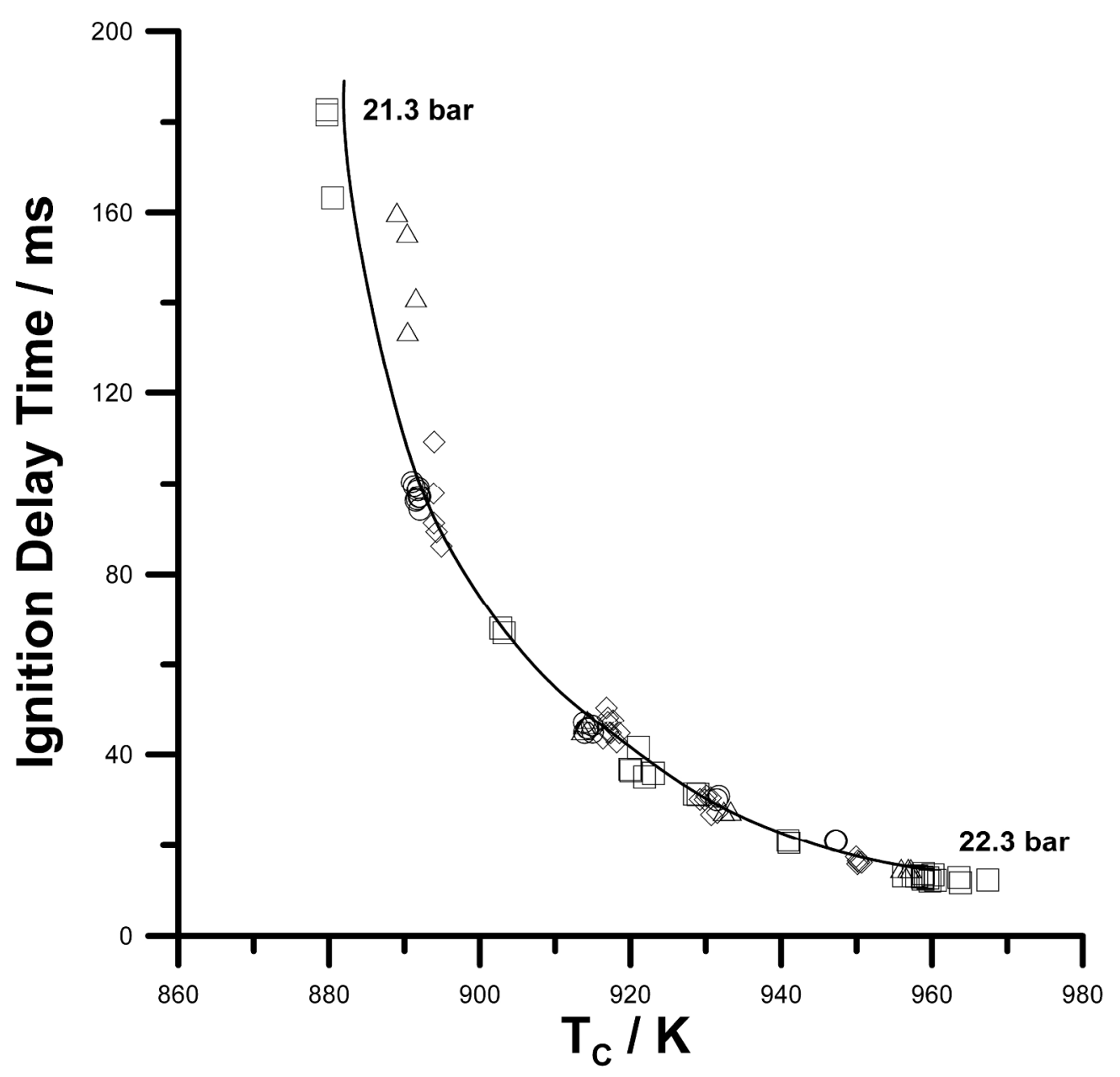

$146 \times 140 \mathrm{~mm}(600 \times 600 \mathrm{DPI})$ 


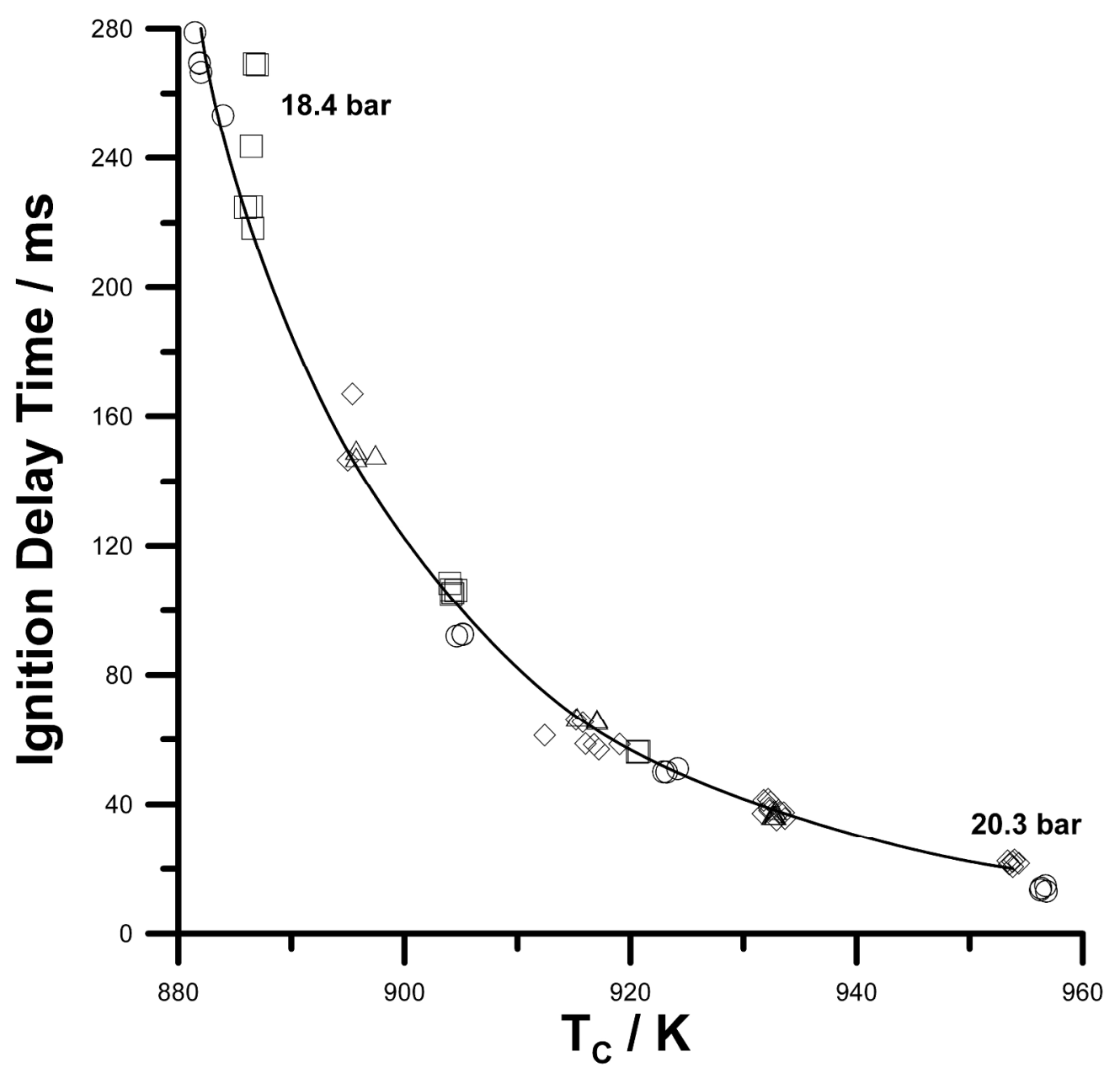

$146 \times 140 \mathrm{~mm}(600 \times 600 \mathrm{DPI})$ 


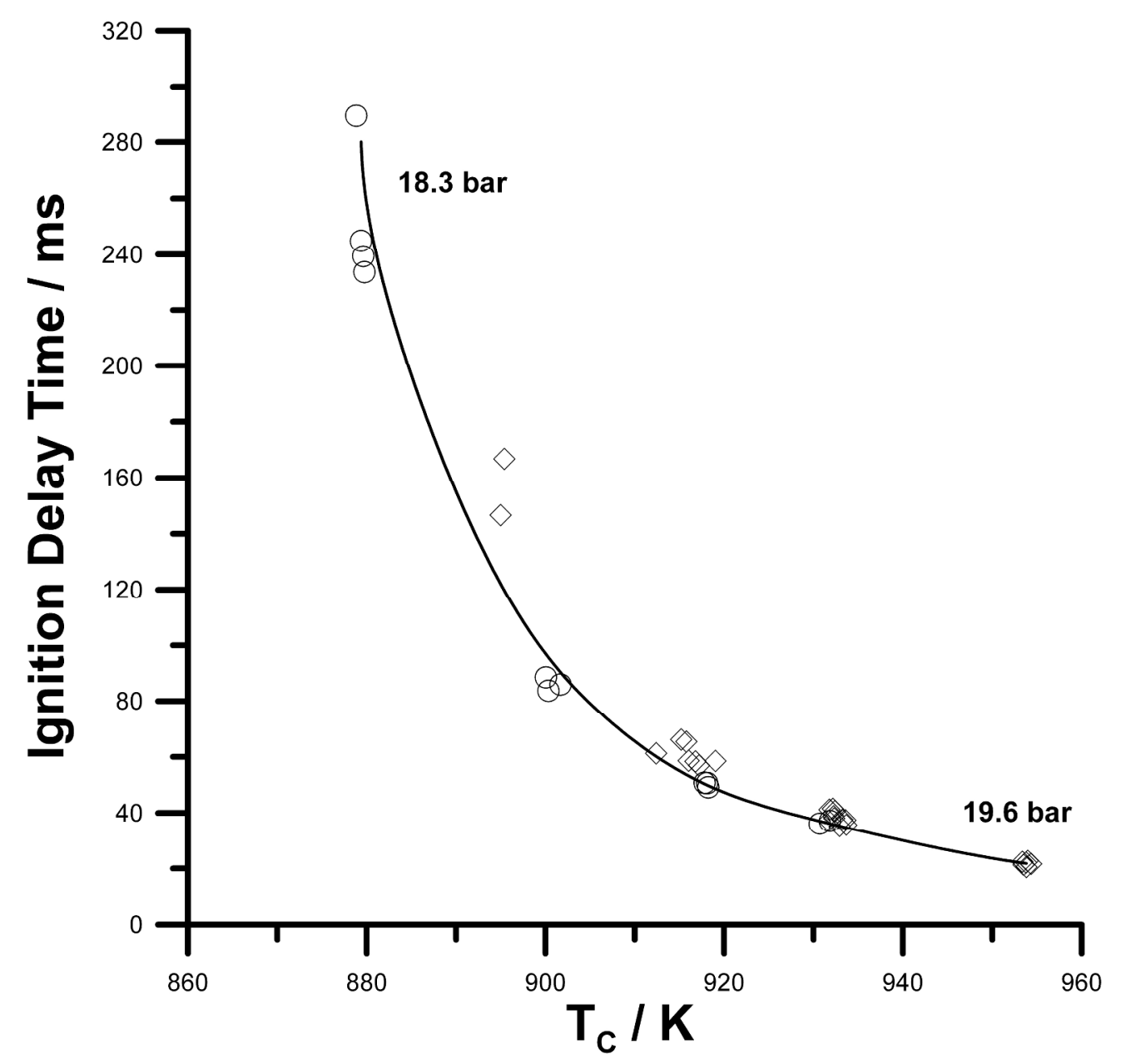

$146 \times 140 \mathrm{~mm}(600 \times 600 \mathrm{DPI})$ 


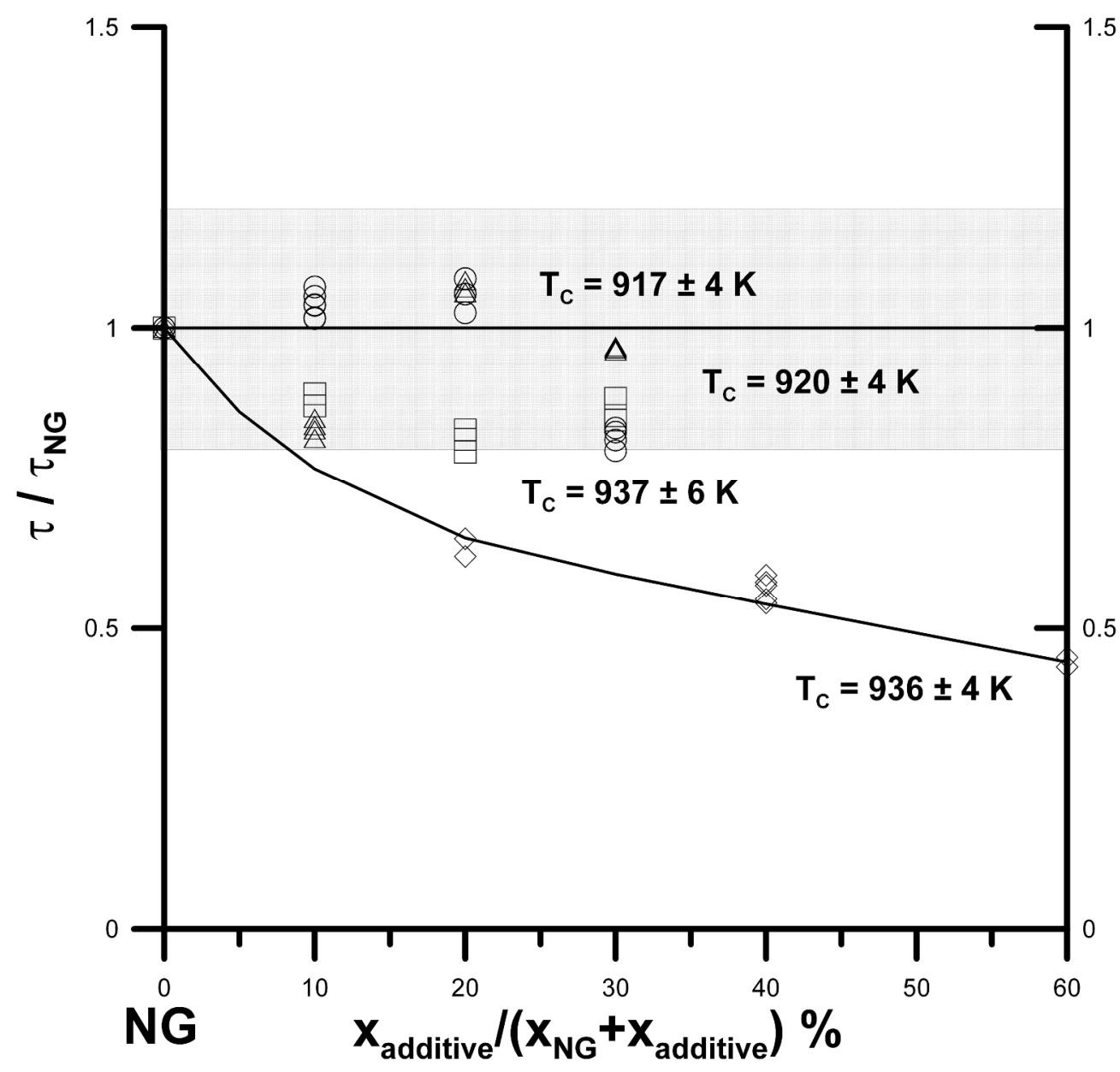

$143 \times 136 \mathrm{~mm}(600 \times 600 \mathrm{DPI})$ 


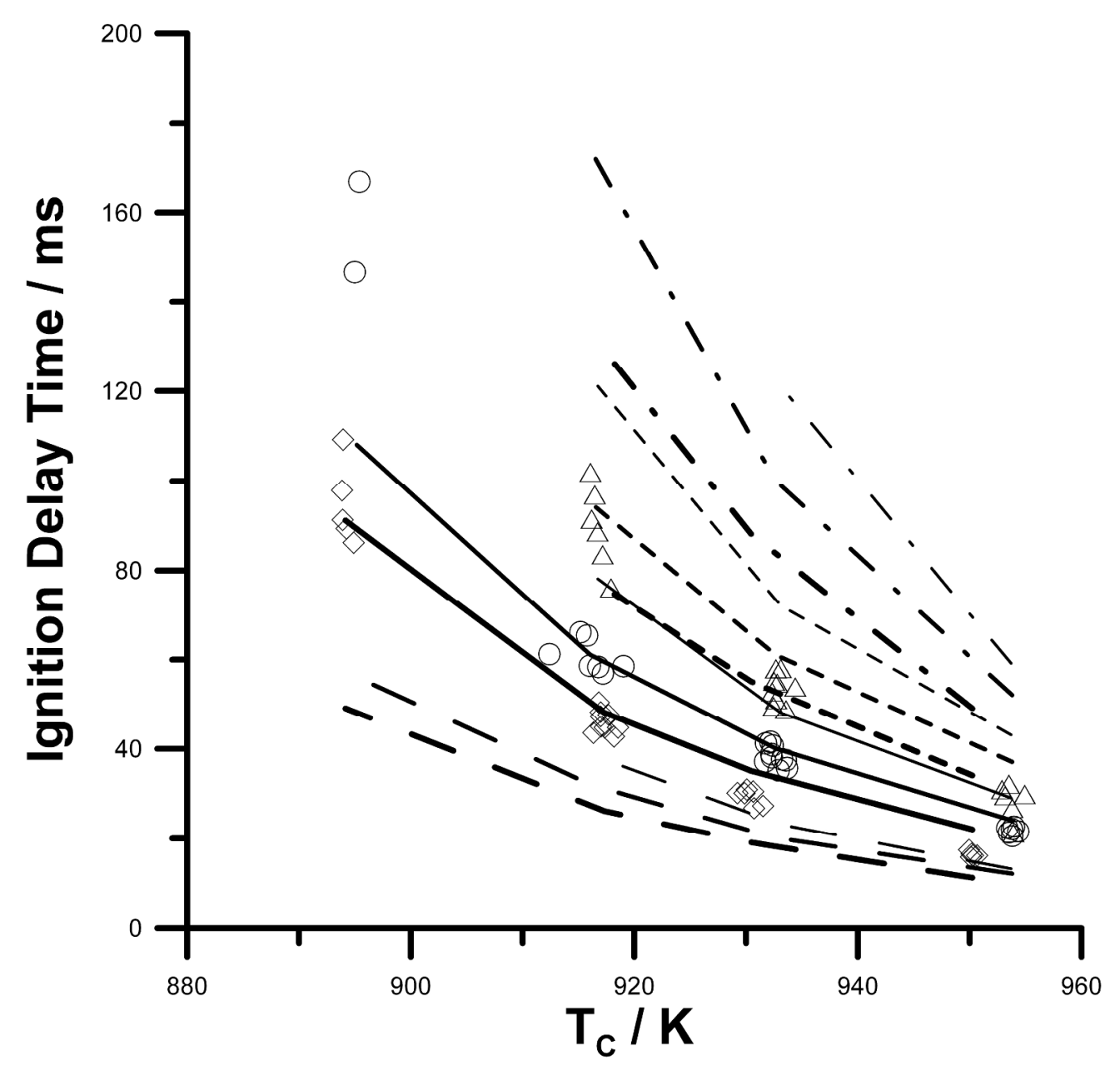

$146 \times 140 \mathrm{~mm}(600 \times 600 \mathrm{DPI})$ 


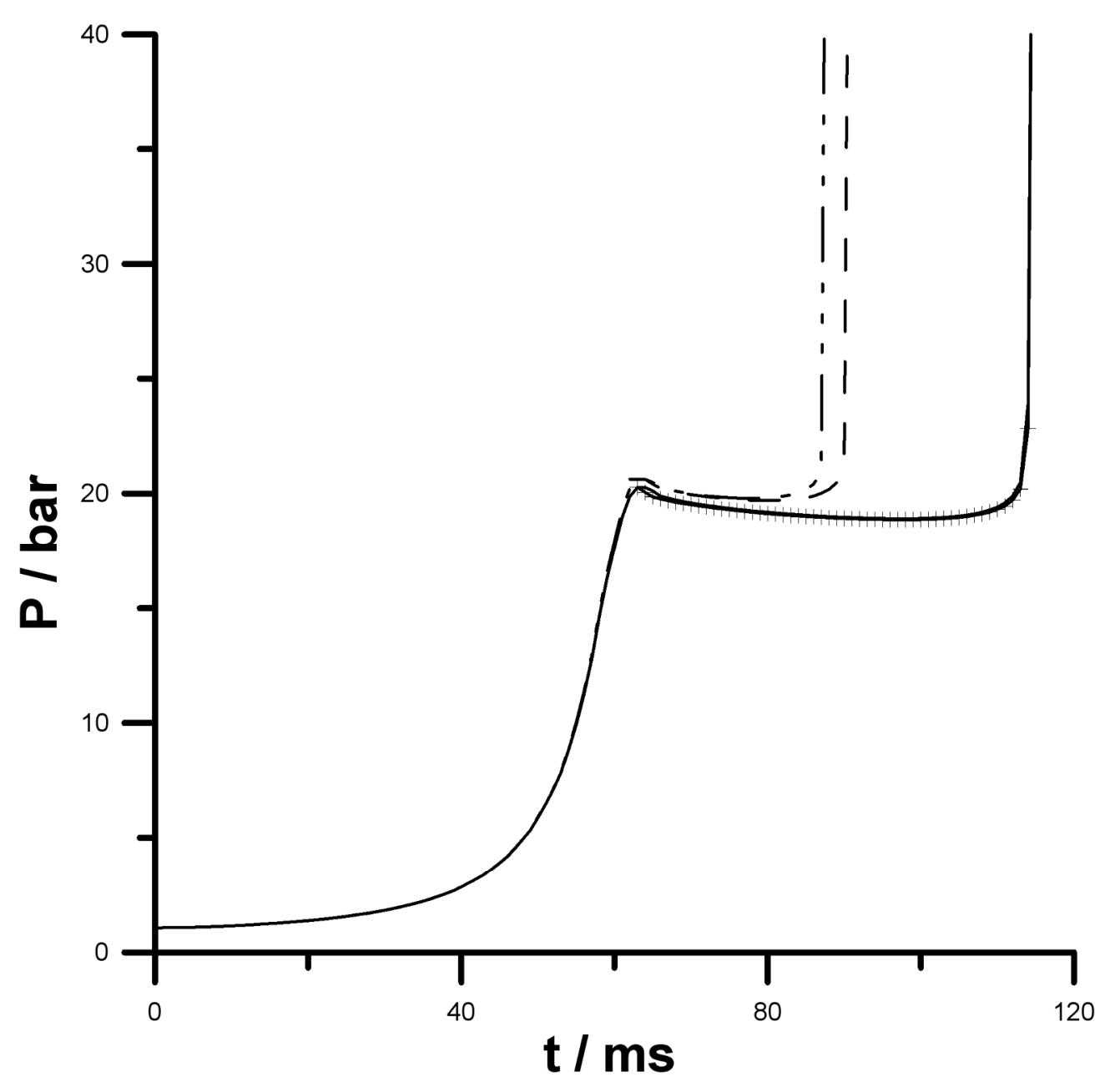

$562 \times 550 \mathrm{~mm}(96 \times 96$ DPI $)$ 


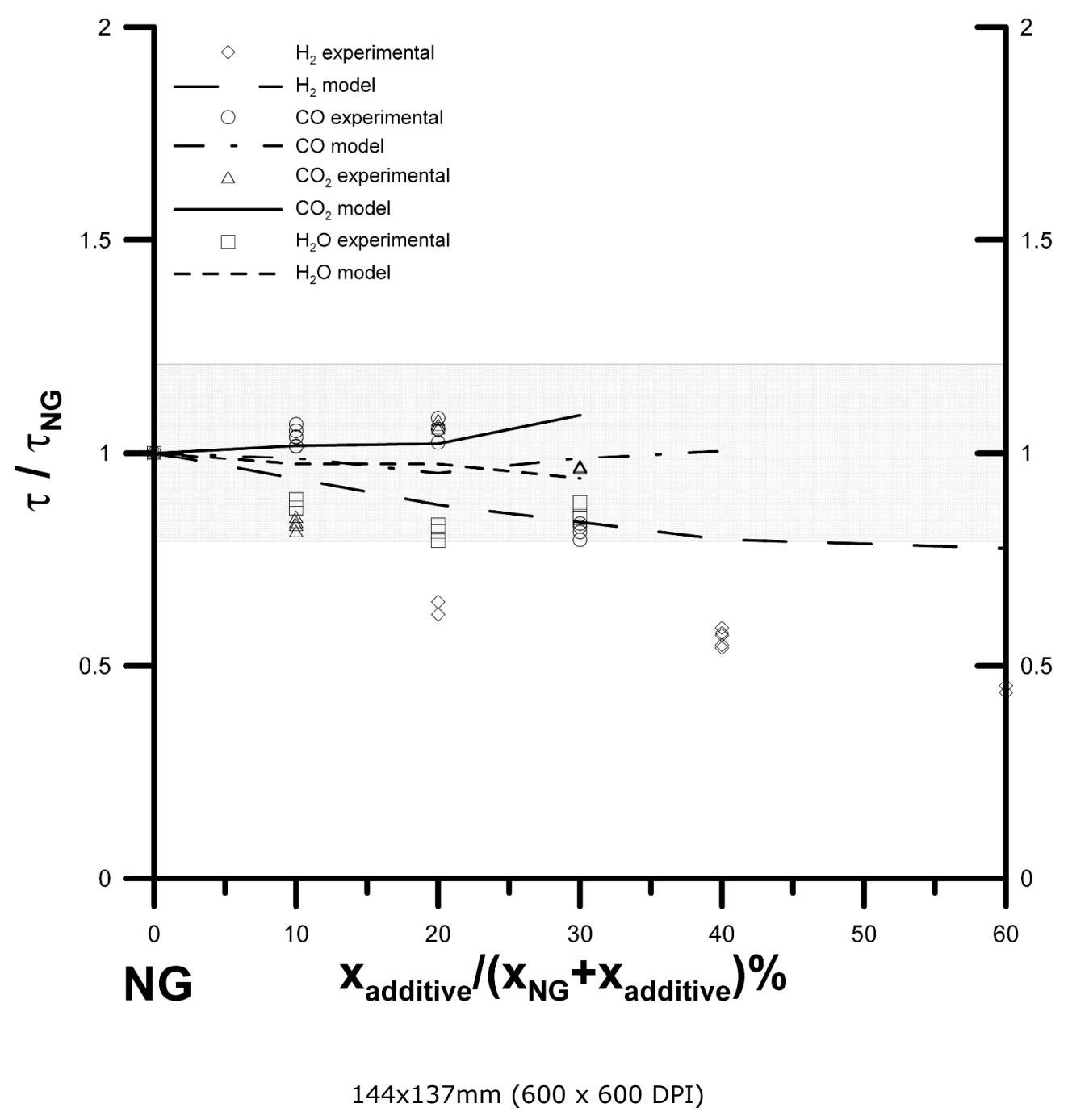

1

2

3

4

5

6

7

8

9

10

11

12

13

14

15

16

17

18

19

20

21

22

23

24

25

26

27

28

29

30

31

32

33

34

35

36

37

38

39

40

41

42

43

44

45

46

47

48

49

50

51

52

53

54

55

56

57

58

59

60 